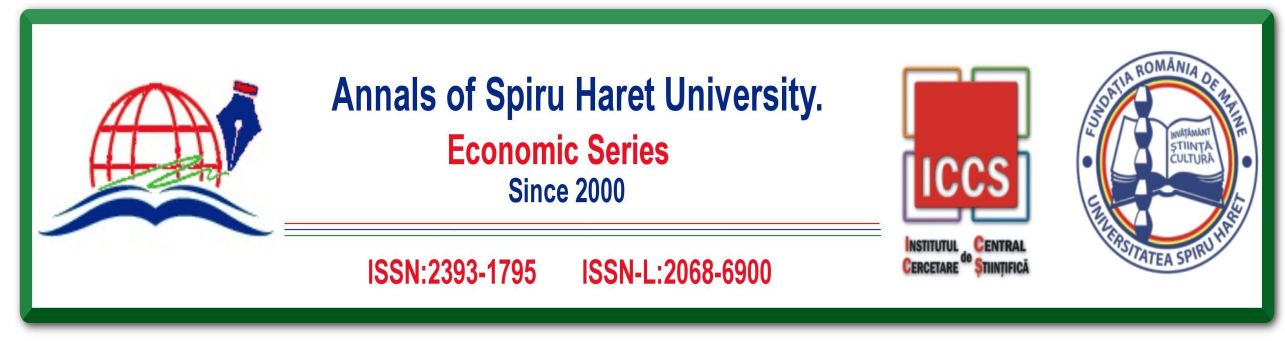

Issue 2/2019

\title{
DOES THE USE OF STRATEGIC MANAGEMENT ACCOUNTING TECHNIQUES CREATES AND SUSTAINS COMPETITIVE ADVANTAGE? SOME EMPIRICAL EVIDENCE
}

\author{
Babajide OYEWO ${ }^{1}$, Solabomi AJIBOLADE ${ }^{2}$ \\ ${ }^{1,2}$ Department of Accounting, University of Lagos, Akoka, Lagos, Nigeria \\ ${ }^{1}$ Corresponding Author, Email: meetjidemichael@gmail.com
}

How to cite: OYEWO, B. \& AJIBOLADE, S. (2019). "Does the Use of Strategic Management Accounting Techniques Creates and Sustains Competitive Advantage? Some Empirical Evidence." Annals of Spiru Haret University. Economic Series, 19(2), 61-91, doi: https://doi.org/10.26458/1923

\footnotetext{
Abstract

This study examined the extent to which the usage of strategic management accounting (SMA) techniques such as customer accounting and competitor accounting can create and sustain competitive advantage, with a focus on the manufacturing sector in Nigeria. Data obtained from the annual reports of fiftysix (56) publicly-quoted companies covering a 10-year period (2008-2017) were analysed using descriptive statistics, cluster analysis, cross tabulation, Chisquare test of association, and discriminant analysis. Whereas the frequency of high-adopters of customer-based and competitor-focused techniques was less than those of low-adopters, the adoption rate of SMA was noted to be generally moderate. Further, the usage of SMA positively and significantly impact competitive advantage. The observation that intense users of SMA were able to consistently outperform competitors at both the industry-and sector-level in the long-term supports the conclusion that, to a large extent, SMA usage can both create and sustain competitive advantage. Seeing that it is not the mere adoption of SMA that sustains competitive advantage but its intense usage, organisations seeking strategies to improve their competitiveness may consider the rigorous application of SMA.
} 


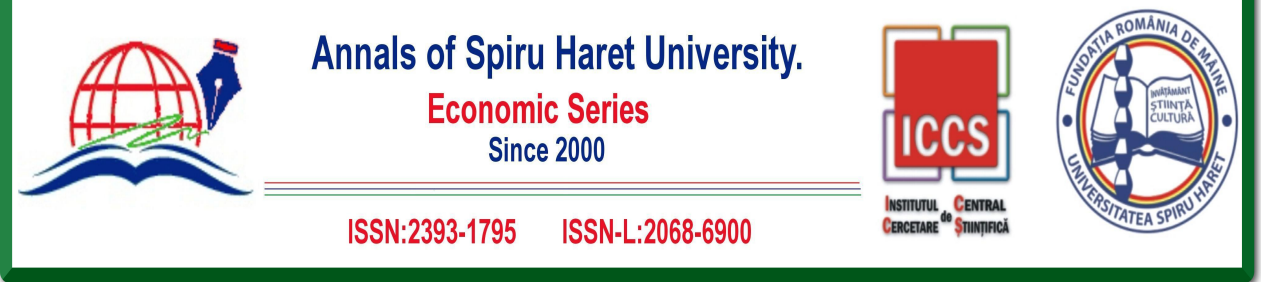

Issue $2 / 2019$

Keywords: competitive advantage; competitor accounting; customer accounting; strategic management accounting; sustainable competitive advantage.

JEL Classification: M4

\section{Introduction}

The remit of the management accounting function is to provide both financial and non-financial accounting information that will assist management at all levels to carry out managerial functions which include but is not limited to planning, control and decision-making. Planning involves establishing the objectives of the organisation and formulating relevant strategies that can be used to achieve those objectives. Planning can be either daily (operational), short-term (tactical) or longterm (strategic). Senior managers formulate long-term objectives (goals) and plans (strategies) for an organisation as a whole. Tactical planning takes the strategic plan and breaks it down into manageable chunks or short-term plans for individual areas of business to enable the strategic plan to be achieved. Senior and middle managers make short- to medium-term plans for the next year. Operational planning involves making day-to-day decisions about what to do next and how to deal with problems as they arise. Decision-making involves considering information that has been provided and making an informed decision. Control involves taking actions to ensure that plans are achieved. Managers use the information relating to actual results to take control measures and to re-assess and amend their original budgets or plans.

Beyond providing information to support management in their duties, management accountants also perform managerial roles such as planning, controlling, performance measurement and decision-making. In performing the planning role, management accountants use budgeting for short-term, medium-term and long-term. The management accountant's role of controlling includes performance evaluation using financial and non-financial performance measures. In the measurement role, management accountants attempt to measure cost, variances and profit, as well as overheads (factory burdens) allocation and apportionment [Ahl, 1999]. In executing decision-making role, management accountants provide information that enhances the quality of decision of management at operational, tactical and strategic levels. Management accountants ought to demonstrate awareness of business imperatives 


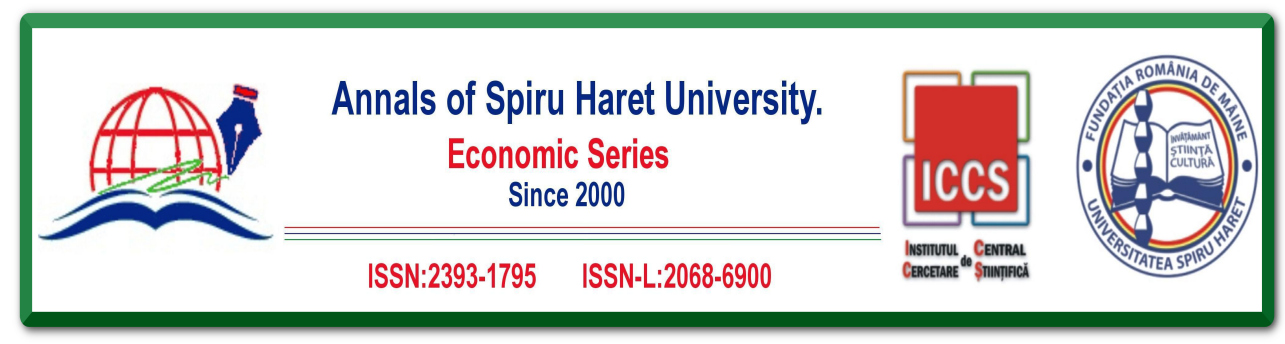

Issue 2/2019

when they provide information for decision-making with inclusion of recommendations [see Ferreira, et al., 2016; Emerton \& Jones, 2019]. In expounding on the supportive role that management accounting provides for management, Simons (1951) cited in BPP (2009a) identifies three attributes of what is now called management accounting, such as score-keeping to see how the organisation is doing overall, attention-directing to indicate area that need to be investigated and problemsolving. It could thus be suggested that there is a connection between management accounting, organisation and society in that management accounting provides information that could enhance organisational effectiveness in achieving set goals; given that the organisation is an integral part of the society, organisational effectiveness is expected to positively affect the society. Thus, management accounting contributes to the society through its impact on the organisation.

Although management accountants perform conventional duties of planning, controlling and decision-making using management accounting techniques tailored to these functions, developments in the competitive business environment is expanding the responsibilities of accountants in business [Chartered Global Management Accountants, CGMA, 2014, 2015] beyond these narrowly-defined functions to now include strategy formulation and implementation. For management accountants to effectively discharge their strategy-related duties, management accounting practice would have to align with developments within and outside the organisation. The management accounting profession has been criticized in the past for failure to reinvigorate management accounting practice to align with changes in the external environment [Oyewo et al., 2019]. This criticism provoked the development of strategy-driven and externally-oriented management accounting techniques called strategic management accounting (hereafter, SMA).

Notwithstanding that SMA as a management accounting concept has existed for a long time in accounting literature (since 1981 that Simmonds coined the terminology) [CIMA, 2002; Hoque, 2002], it is still being depicted as elusive [Roslender \& Hart, 2002]. Most literature regarding SMA is at the conceptual levels, with little evidences from empirical studies [Subasinge \& Fonseka, 2009]. It is paradoxical that there is high interest in SMA, yet empirical investigation is minimal [Langfield-Smith, 2008; Pavlatos, 2011]. There is need for more research as SMA is a vast field. The prevalence of studies on traditional management accounting (TMA) in management accounting literature reinforces the contention that SMA is largely an untapped research area [Cadez \& Guilding, 2008; Al-Mawali, 2015]. Debates on the adoption rate and the benefits of SMA usage, amongst other issues, are still unsettled. 


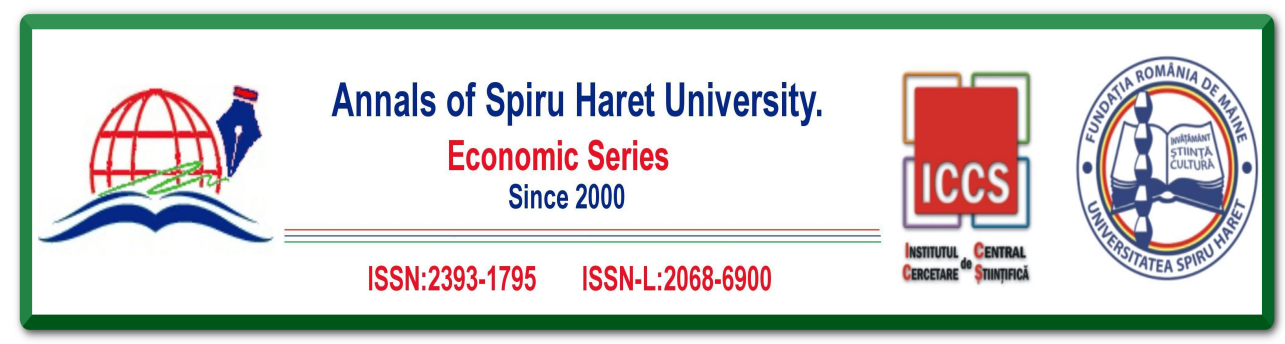

Issue 2/2019

There is a body of literature suggesting that SMA has been widely-adopted in developed countries including The United States of America (USA), Australia, United Kingdom, Finland, and Greece [see Cadez \& Guilding, 2008; Abdel Al \& McLellan, 2011; Abogun \& Abomide, 2013; Abdullah \& Said, 2015]. Diffusion of management innovations exists within nations but may differ across countries; thus, results on SMA adoption rate may not be generalisable. Considering that the role and organisational positioning of management accounting inevitably differs across organisations, cultures and countries [Ahmad \& Zabri, 2015], the need to conduct country-specific studies on issues touching on SMA is crucial, especially in developing countries where the subject matter of SMA is under-researched including Nigeria.

The state of research on SMA in Nigeria still leaves much to be desired as the subject is yet to be rigorously investigated. Although some investigations have been conducted on sophisticated management accounting techniques, studies on TMA still dominate the management accounting literature. The paucity of studies on SMA in the Nigerian context has been documented by scholars [Ajibolade, 2010; Akenbor \& Okoye, 2012; Abogun \& Abomide, 2013; Oboh \& Ajibolade, 2017]. Little is known on the adoption rate of SMA by companies operating in Nigeria. In lending credence to the paucity of empirical research on SMA in Nigeria, Akenbor \& Okoye (2012) submit that despite the publicity SMA has received as a new direction that gives competitive edge to organisations, dearth of empirical studies on its adoption persists. In support, Abogun \& Abomide, (2013, p. 23) lament that "there is however little evidence in this part of the world on the adoption level of these [SMA] initiatives and consequently its impact on the performance of firms in Nigeria".

Literature suggests that benefits such as value-creation, better strategic decisionmaking and gaining competitive advantage may ensue from the application of SMA [Aboramadan \& Borgonovi, 2016; Holm, Kumar \& Plenborg, 2016; Oboh \& Ajibolade, 2017; Ojua, 2017]. Applying SMA to achieve sustainable competitive advantage is particularly applicable to companies operating in Nigeria. This is because the performance of a number of companies in Nigeria has been unsatisfactory $[\mathrm{Ku}$ et al., 2010], and the deployment of SMA as an innovative management accounting practice could be a strategy to reinvigorate their competitiveness. However, empirical evidence on the outcomes of SMA usage in relation to creating and sustaining competitive advantage is still lacking. The motivation to undertake this research, using the manufacturing sector in Nigeria as a basis for study, stems from these observations. 64 


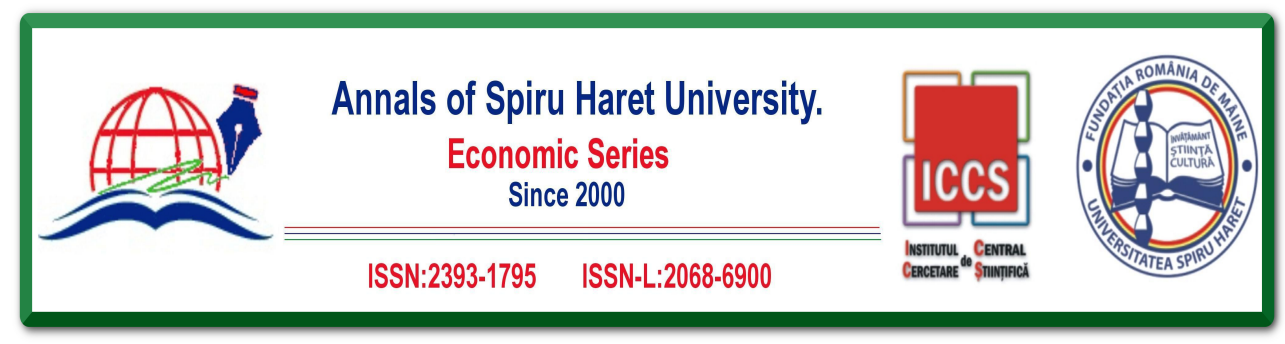

Issue 2/2019

The objectives of the study are to: (i) determine the adoption rate of SMA; (ii) assess the impact of SMA usage on the competitiveness of companies; and (iii) evaluate the extent to which SMA usage can sustain competitive advantage.

Data obtained from the annual reports of fifty-six (56) publicly-quoted companies covering a 10-year period (2008-2017) were analysed using descriptive statistics, cluster analysis, cross tabulation, Chi-Square Tests of association, and discriminant analysis. Whereas the frequency of high-adopters of customer-based and competitorfocused techniques was less than those of low-adopters, the adoption rate of SMA was noted to be generally moderate. Further, the usage of SMA positively and significantly impact competitive advantage. The observation that intense users of SMA were able to consistently outperform competitors at both the industry- and sector-level in the long-term supports the conclusion that to a large extent, SMA usage can both create and sustain competitive advantage. Seeing that it is not the mere adoption of SMA that sustains competitive advantage but its intense usage, organisations seeking strategies to improve their competitiveness may consider the rigorous application of SMA.

The remaining part of the paper is organised into five Sections (2-6). Section 2 focuses on literature review and development of research hypotheses. After expounding on methodology in Section 3, results \& analyses are covered in Section 4, followed by discussion of findings in Section 5. The paper is concluded in section 6 .

\section{Literature Review and Hypothesis Development}

\subsection{The Concept of Strategic Management Accounting}

Various definitions have been attributed to the SMA terminology by scholars. Simmonds' (1981) initial conceptualisation of SMA was a collection of externallyorientated management accounting techniques that analyse data about a business and its competitors, used to develop and monitor the strategy of a business. The definition of strategic management accounting (SMA) has since undergone some refinements. Acknowledging that there is no comprehensive, universally-acceptable framework available in SMA literature [Roslender \& Hart, 2003; Agasisti et al., 2008; Yap et al., 2013], newer attempts have been made to define the concept. Cooper \& Kaplan (1988) state that strategic accounting techniques are designed to support the overall competitive strategy of the organisation in developing more refined product and service costs. Shank \& Govindarajan (1989) regard SMA as the managerial use of cost information explicitly directed at the stages of the strategic management cycle. 


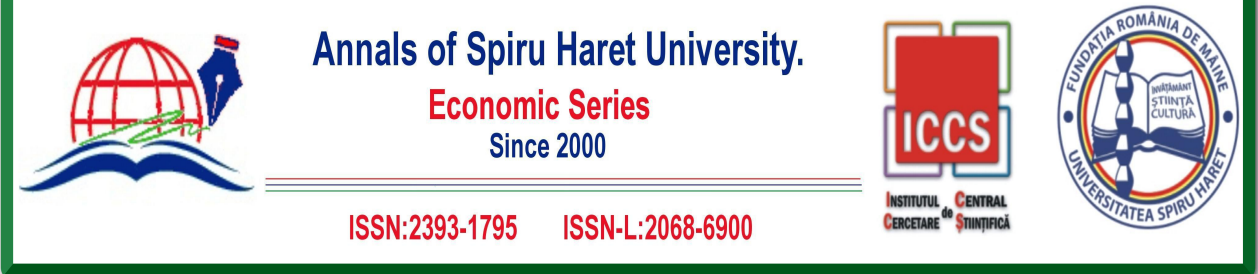

Issue 2/2019

SMA consists of techniques that can lead to value-creation in organisations [Abdullah \& Said, 2015], and can support strategic decisions such as pricing, outsourcing, process improvement, business process re-engineering (BPR). The Chartered Institute of Management Accountants (CIMA) cited in BPP (2009b) clarifies that SMA could provide information such as competitor costs, financial effect of competitor response, financial effect of competitor response, product profitability, customer profitability, pricing decisions, value of market share, capacity expansion, brand valuation, shareholder wealth, cash-flow, effect of acquisitions and mergers, decisions to enter or leave a business area, and introduction of new technology. In sum, SMA refers to the collection of modern and sophisticated management accounting techniques that focus on customers, competitors and other strategic issues including strategic planning, control, performance measurement, and decision-making.

The emergence of SMA techniques has been diverse, contradictory and iterative as the techniques have witnessed continuous addition and updating [Cinquini \& Tenucci, 2007; Noordin et al., 2009]. However, a widely applied taxonomy for grouping SMA techniques was developed by Cadez \& Guilding (2008). By deriving sixteen (16) SMA techniques from prior studies, Cadez \& Guilding (2008) refine the classification of the techniques into five broad groups of (i) costing; (ii) planning, control and performance measurement; (iii) strategic decision-making; (iv) competitor accounting; and (v) customer accounting. They argue that the first three groups align with the underlying theme of management accounting (costing, planning, control, performance management and decision-making), while the remaining two (competitor accounting and customer accounting) fall outside the purview of conventional management accounting but within the realm of SMA. The techniques under each category are as follows: (i) Costing including Attribute costing, Life-cycle costing, Quality costing, Target costing and, Value-chain costing; (ii) Planning, control and performance measurements including; Benchmarking, Integrated performance measurement; (iii) Strategic decision-making including: Strategic costing (also called strategic cost management), Strategic pricing and, Brand valuation; (iv) Competitor Accounting including: Competitor cost assessment, Competitive position monitoring and, Competitor performance appraisal; and (v) Customers Accounting including: Customer profitability analysis, Lifetime customer profitability analysis and, Valuation of Customers as Assets. 

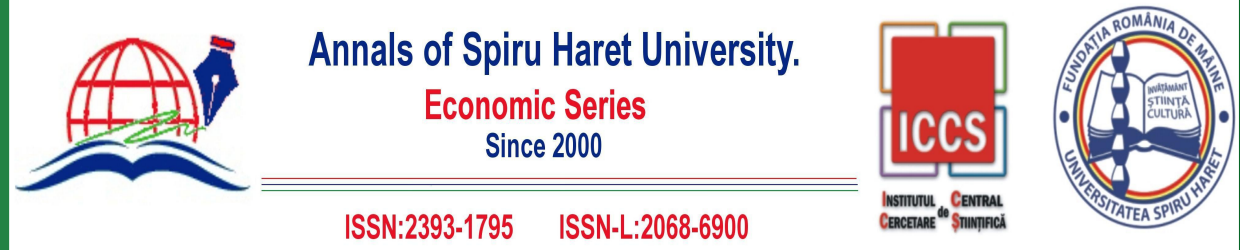

Issue 2/2019

Cadez \& Guilding's (2008) taxonomy did not capture some SMA techniques investigated in other studies such as Activity Based Costing (ABC) / Activity Based Management [see Shank \& Govindarajan, 1992; Ahl, 1999; Pavlatos \& Paggios, 2007; CIMA cited BPP 2008; Alsoboa et al., 2015], and Environmental Management Accounting [Alsoboa et al., 2015]. While Guilding, Cravens \& Tayles (2000), and Yap et al. (2013) exclude ABC among SMA technique, Shank \& Govindarajan (1992) and Ahl (1999) consider it as one of the techniques.

Table 1 reveals this study's conceptualisation of SMA techniques as adapted from prior studies. This is made up of 16 techniques from Cadez \& Guilding's (2008) list, with the addition of three (3) techniques (ABC, ABM and Environmental Management Accounting in asterisks) based on the review of literature, making a total of nineteen (19) techniques.

Table 1. Clustering of SMA Techniques

\begin{tabular}{|l|l|l|l|}
\hline Category & Technique & Description \\
\hline & 1 & $\begin{array}{l}\text { Attribute } \\
\text { costing }\end{array}$ & $\begin{array}{l}\text { The costing of specific product attributes } \\
\text { that appeal to customers such as operating } \\
\text { performance variables; reliability, warranty } \\
\text { arrangements, and after sales service }\end{array}$ \\
\cline { 2 - 4 } Costing & $\begin{array}{l}\text { Life cycle } \\
\text { costing }\end{array}$ & $\begin{array}{l}\text { The appraisal of costs based on the length of } \\
\text { stages of a product's life including design, } \\
\text { introduction, growth, maturity, decline and } \\
\text { eventually abandonment }\end{array}$ \\
\cline { 2 - 4 } & 3 & Quality costing & $\begin{array}{l}\text { Prioritising quality by identification and } \\
\text { control of the costs associated with the } \\
\text { creation, identification, repair and } \\
\text { prevention of defects }\end{array}$ \\
\cline { 2 - 4 } & 4 & $\begin{array}{l}\text { A method used during product and process } \\
\text { design that involves estimating a cost } \\
\text { calculated by subtracting a desired profit } \\
\text { margin from an estimated (or market-based) } \\
\text { price. The product is then designed to meet } \\
\text { that cost }\end{array}$ \\
\hline & $\begin{array}{l}\text { An activity-based approach where costs are } \\
\text { allocated to activities required to design, }\end{array}$ \\
\hline
\end{tabular}




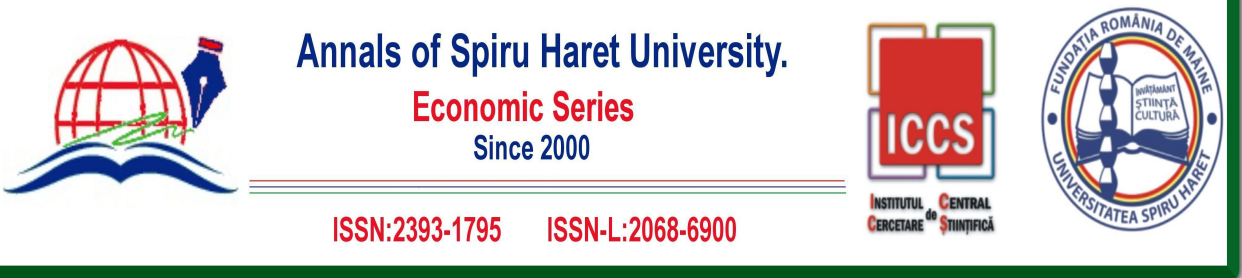

Issue 2/2019

\begin{tabular}{|c|c|c|c|}
\hline & & & $\begin{array}{l}\text { procure, produce, market, distribute, and } \\
\text { service a product or service }\end{array}$ \\
\hline & 6 & $\begin{array}{l}\text { Activity based } \\
\text { costing* }\end{array}$ & $\begin{array}{l}\text { A two-stage procedure used to assign } \\
\text { overhead costs to products. In the first stage, } \\
\text { significant activities are identified, and } \\
\text { overhead costs are assigned to activity cost } \\
\text { pools in accordance with the way the } \\
\text { resources are consumed by the activities. In } \\
\text { the second stage, overhead costs are } \\
\text { allocated from each activity cost pool to } \\
\text { each product line in proportion to the } \\
\text { amount of the cost driver consumed by the } \\
\text { product line }\end{array}$ \\
\hline & 7 & $\begin{array}{l}\text { Activity based } \\
\text { management* }\end{array}$ & $\begin{array}{l}\text { The use of information provided by an } \\
\text { activity cost analysis (ABC) to improve } \\
\text { organisational profitability }\end{array}$ \\
\hline \multirow{3}{*}{$\begin{array}{l}\text { Planning, control } \\
\text { and performance } \\
\text { measurement }\end{array}$} & 1 & Benchmarking & $\begin{array}{l}\text { The comparison of internal processes to an } \\
\text { ideal standard. }\end{array}$ \\
\hline & 2 & $\begin{array}{l}\text { Integrated } \\
\text { performance } \\
\text { measurement }\end{array}$ & $\begin{array}{l}\text { A measurement system which focuses } \\
\text { typically on acquiring performance } \\
\text { knowledge based on customer requirements } \\
\text { and may encompass nonfinancial measures }\end{array}$ \\
\hline & 3 & $\begin{array}{l}\text { Environmental } \\
\text { Management } \\
\text { Accounting* }\end{array}$ & $\begin{array}{l}\text { The practice of tracking, tracing and } \\
\text { treatment of costs, earnings and savings } \\
\text { incurred in relation to the company's } \\
\text { environmental-related activities }\end{array}$ \\
\hline \multirow{3}{*}{$\begin{array}{l}\text { Strategic decision } \\
\text { making }\end{array}$} & 1 & $\begin{array}{l}\text { Strategic } \\
\text { costing } \\
\text { (strategic cost } \\
\text { management) }\end{array}$ & $\begin{array}{l}\text { The use of cost data based on strategic and } \\
\text { marketing information to develop and } \\
\text { identify superior strategies that will produce } \\
\text { a sustainable competitive advantage }\end{array}$ \\
\hline & 2 & $\begin{array}{l}\text { Strategic } \\
\text { pricing }\end{array}$ & $\begin{array}{l}\text { The analysis of strategic factors, such as } \\
\text { competitor price reaction, elasticity, market } \\
\text { growth, and economies of scale, in the } \\
\text { pricing decision process }\end{array}$ \\
\hline & 3 & $\begin{array}{l}\text { Brand } \\
\text { valuation }\end{array}$ & $\begin{array}{l}\text { The financial valuation of a brand through } \\
\text { the assessment of brand strength factors } \\
\text { such as: leadership, stability, market, }\end{array}$ \\
\hline
\end{tabular}




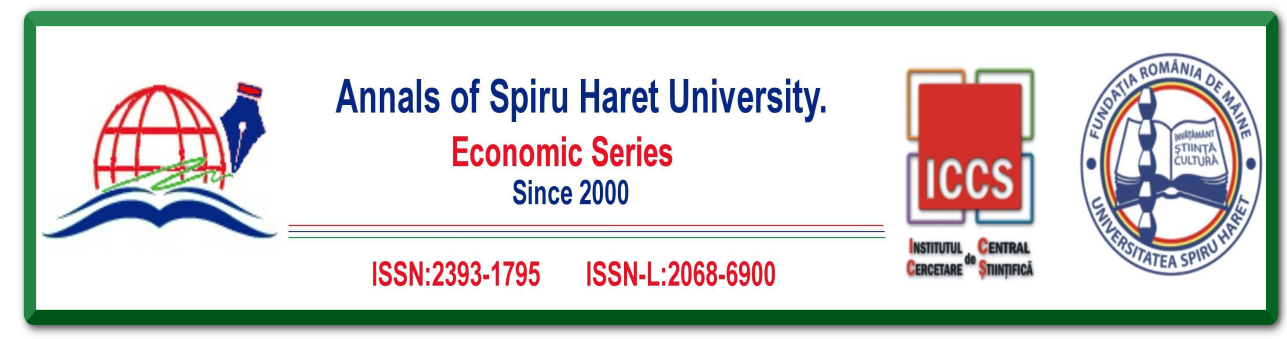

Issue 2/2019

\begin{tabular}{|c|c|c|c|}
\hline & & & $\begin{array}{l}\text { internationality, and trend, combined with } \\
\text { historical brand profits }\end{array}$ \\
\hline \multirow[t]{3}{*}{$\begin{array}{l}\text { Competitor } \\
\text { Accounting }\end{array}$} & 1 & $\begin{array}{l}\text { Competitor } \\
\text { cost } \\
\text { assessment }\end{array}$ & $\begin{array}{l}\text { The provision of regularly scheduled } \\
\text { updated estimates of a competitor's unit cost }\end{array}$ \\
\hline & 2 & $\begin{array}{l}\text { Competitive } \\
\text { position } \\
\text { monitoring }\end{array}$ & $\begin{array}{l}\text { The analysis of competitor positions within } \\
\text { the industry by assessing and monitoring } \\
\text { trends in competitor sales, market share, } \\
\text { volume, unit costs, and return on sales }\end{array}$ \\
\hline & 3 & $\begin{array}{l}\text { Competitor } \\
\text { performance } \\
\text { appraisal }\end{array}$ & $\begin{array}{l}\text { The numerical analysis of a competitor's } \\
\text { published statements as a part of an } \\
\text { assessment of a competitor's key sources of } \\
\text { competitive advantage }\end{array}$ \\
\hline \multirow[t]{3}{*}{$\begin{array}{l}\text { Customer } \\
\text { Accounting }\end{array}$} & 1 & $\begin{array}{l}\text { Customer } \\
\text { profitability } \\
\text { analysis }\end{array}$ & $\begin{array}{l}\text { Calculating profit earned from a specific } \\
\text { customer based on costs and sales that can } \\
\text { be traced to a particular customer }\end{array}$ \\
\hline & 2 & $\begin{array}{l}\text { Lifetime } \\
\text { customer } \\
\text { profitability } \\
\text { analysis }\end{array}$ & $\begin{array}{l}\text { Extending the time horizon for customer } \\
\text { profitability analysis to include future years. } \\
\text { The practice focuses on all anticipated } \\
\text { future revenue streams and costs involved in } \\
\text { servicing a particular customer }\end{array}$ \\
\hline & 3 & $\begin{array}{l}\text { Valuation of } \\
\text { customers as } \\
\text { assets }\end{array}$ & $\begin{array}{l}\text { A technique that involves the calculation of } \\
\text { the value of customers to the company. This } \\
\text { may involve computing the present value of } \\
\text { all future profit streams attributable to a } \\
\text { particular customer }\end{array}$ \\
\hline
\end{tabular}

Source: Authors' compilation (2019)

There is need for strategy and, by extension, the use of SMA techniques in the contemporary business environment to survive and outsmart competitors. As management would be interested in enshrining qualitative, behavioural, motivational and environmental concerns in organisational strategy [Kaplan, 2013], these non-financial factors are often more difficult to estimate and quantify, thus requiring the adroitness of management accountants. The management accounting function will have to therefore support management in strategy formulation and implementation through the use of SMA techniques [Bromwich \& Bhimani 1994]. 


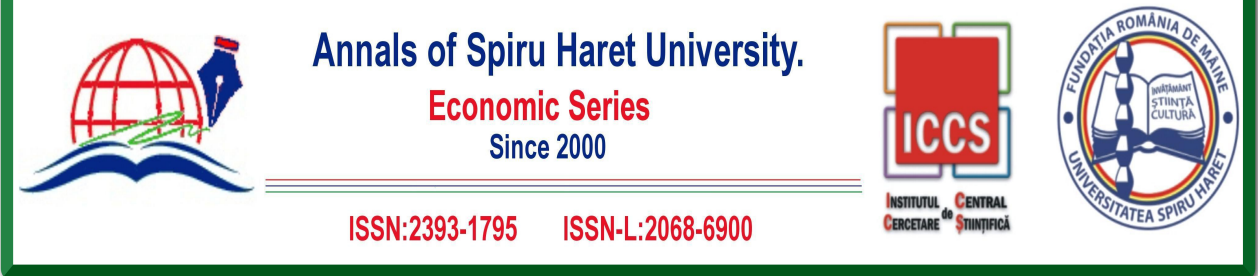

Issue 2/2019

Consequent on the diffusion of SMA, management accountants are now seen as strategic partners on the account of their involvement in the implementation of business imperatives [CGMA, 2014, 2015; Pitcher, 2015].

\subsection{Strategic Management Accounting and Sustainable Competitive Advantage}

The disapproval of TMA techniques restricted to planning, control and decisionmaking within the organisation, devoid of any external orientation undoubtedly paved way for the emergence of SMA [Bhimani \& Bromwich, 1992; Drury, 1992]. The limitations of TMA such as internal focus and restriction to analysis of structured, quantitative data [Bromwich \& Bhimani, 1989], concentration on operational issues [Chenhall \& Langfield-Smith, 1998], and inappropriateness for strategy formulation, monitoring and implementation [Kaplan \& Atkinson, 1989] should ordinarily rouse the switch from TMA to SMA by any organisation that wants to bolster its competitiveness in the complex business environment. This is because SMA can create considerable value by providing more relevant information that is required for the success of modern day organisations [Guilding et al., 2000; Aboramadan \& Borgonovi, 2016; Ojua, 2017].

Benefits of SMA usage may therefore be expected in the way of gaining and sustaining competitive advantage [International Federation of Accountants, IFAC, 1998; Roslender \& Hart, 2002; Oboh \& Ajibolade, 2017]. Competitive Advantage refers to superior performance of an organisation over other organisations operating in the same industry [Holm et al., 2016]. Studies have linked competitive advantage to organisational performance [see Porter \& Millar, 1985; Barney, 2002; Kushwaha, 2011; Njuki et al., 2013]. The long-term orientation and the future outlook characterising SMA suggest that its application should enable organisations sustain competitive advantage by consistently improving and maintaining an above-industry-average performance not only in the short-run but also in the medium- to long-term. Dimensions of competitive advantage which may accrue on the account of SMA usage are financial and non-financial such as customer satisfaction, product development, product quality and financial returns.

In spite of the submissions on the benefits of SMA adoption, some scholars have doubted the essence of its usage, claiming that little is known on the value it adds to the organisation [see Lord, 1996; Tomkins \& Carr, 1996; Mevellec \& Lebas, 2010 cited in Abdullah \& Said, 2015]. For instance, whilst Sulaiman, Ahmad \& Alwi's 70 


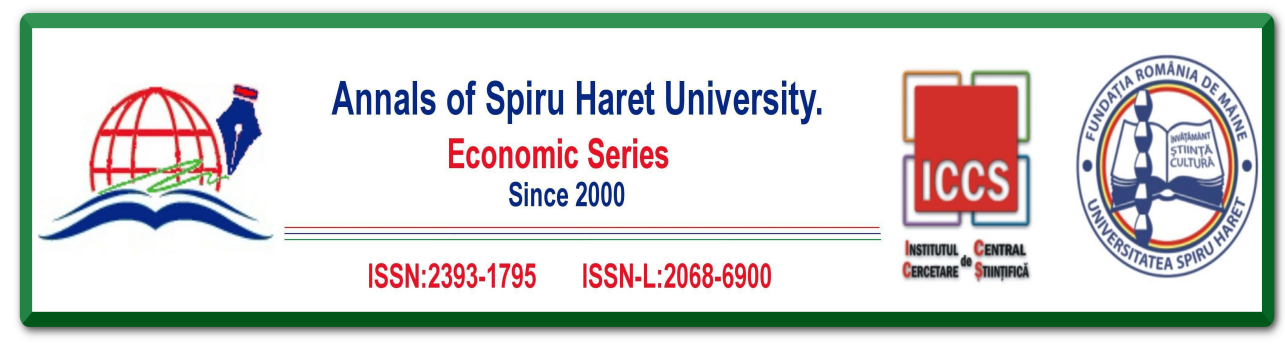

Issue 2/2019

study (2004) finds that management accounting practices help to create value, Mevellec \& Lebas (2010) counter that many medium-sized firms are doing well with minimal adoption or no application of management accounting techniques in some instances. They contend that large-sized firms have been shown to respond slowly to implementing management accounting tools which result to underperformance of firms; hence the use of SMA may not therefore add value as anticipated. Overall, investigations on the benefits of SMA adoption report mixed outcomes. While some studies report positive association between SMA usage and superior performance [Cadez \& Guilding, 2008; Abdel Al \& McLellan, 2011; Fowzia, 2011; Akenbor \& Okoye, 2012; Abdel Al, \& McLellan, 2013; Abogun \& Abomide, 2013; Eker \& Aytaç, 2016; Oboh \& Ajibolade, 2017], others report low benefits [see Hyvonen, 2005; Angelakis et al., 2010; Yap et al., 2013). However, this study posits that:

H1: The usage of SMA has a significant positive impact on sustainable competitive advantage of companies.

\section{Methodology}

\subsection{Population and Sample Selection}

The population of the study is comprised of manufacturing companies listed on the main board (first-tier security market) of the Nigerian Stock Exchange (NSE). A sampling frame of all companies engaging in manufacturing activities was constructed based on the categories of industry sector provided by the NSE. Using this criterion, as at December 2017, seven industry sectors emerged in the categories of Agriculture (4), Consumer Goods (21), Healthcare (8), Industrial Goods (17), Conglomerate (5), Natural Resources (4), and Information \& Communications Technology (3) making a total of 62 firms.

On the list, 4 firms have discontinued operations, 1 firm merged with another, and 1 firm is no longer engaged in manufacturing activities but trading business. These 6 firms were excluded from the study, leaving a total of 56 firms in the categories of Agriculture (4), Consumer Goods (18), Healthcare (7), Industrial Goods (16), Conglomerate (5), Natural Resources (4), and Information \& Communications Technology (2). All the 56 remaining firms were selected. Thus the study applied a census survey. A census involves the inclusion of all elements of the population of a study in the sample selection. Since one hundred percent response rate is unlikely, the use of census survey is justified in this study to ensure the sample is large enough for statistical analysis. 


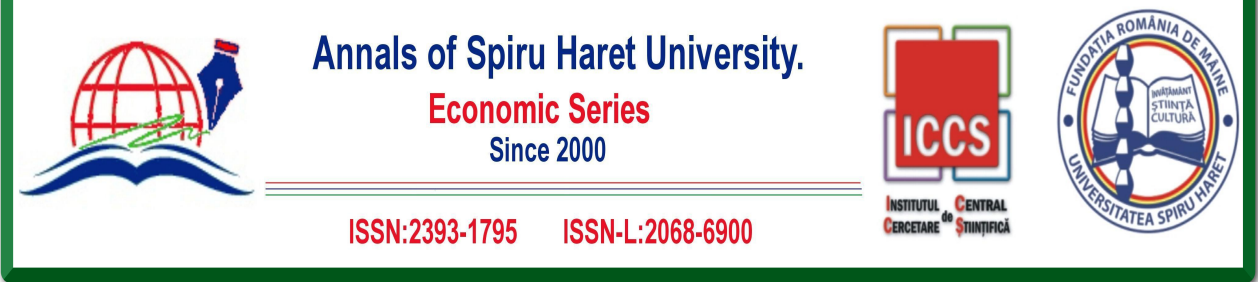

Issue 2/2019

\subsection{Data-Collection Method}

Data were collected from the annual reports of the fifty-six (56) study companies covering a 10-year period (2008 to 2017). Since the companies are publicly-quoted, their audited published accounts are widely circulated and are available in the public domain.

\subsection{Measurement of Variables}

\section{(i) SMA Adoption}

SMA adoption was measured through a scale developed by the researcher, bearing in mind the aspects of SMA that are usually disclosed through annual reports. Unlike other categories of SMA practice (costing; planning, control \& performance measurement; and strategic decision-making techniques) that are seldom disclosed in company documents available in the public domain, annual reports typically contain assertions on customers'/distributors' activities and competitors' actions. Thus, the study focused on evaluating customer-based and competitor-focused SMA techniques divulged in annual reports of study companies.

Three (3) measures of customer accounting were developed: (i) disclosure on tracking of turnover, cost, and profitability per customer; (ii) naming of major customers/ key accounts/ main distributors; (iii) discussion on activities of distributors in reaching customers or enhancing sales operations [this is premised on the philosophy that organisations could deploy superior distribution network and retail capabilities to increase customer engagement]. Further, four (4) measures of competitor accounting were developed such as; (i) mention of company's position in relation to competitors; (ii) impact of competitors' action on the company's activities; (iii) Naming of competitors/ disclosure on the number of competitors; (iv) disclosure on strategy to improve competitive position/ outperform competitors in the future. Altogether, these seven (7) items were used to gauge the adoption rate of SMA. The checklist was validated by three experts (a senior Academic specialising in Management Accounting and two well-experienced Management Consulting experts who are both ICAN (The Institute of chartered Accountants of Nigeria) and CIMA (Chartered Institute of Management Accountants, UK) qualified. The feedbacks obtained from the critiquing were used to sharpen the measurement instrument.

The annual reports of companies were content-analysed for disclosure in respect of these items and scored accordingly using the checklist. If disclosure was made in respect of an item, it is scored ' 1 ', and no disclosure is assigned ' 0 '. The use of the 


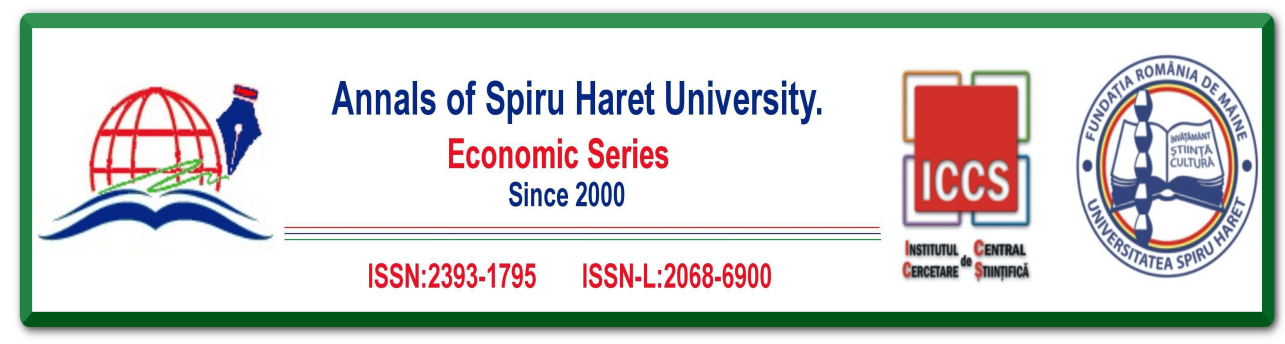

Issue 2/2019

annual reports as a source of gauging the adoption of SMA is informed by the consideration that such reports are mainstream in communicating financial and nonfinancial information to stakeholders. As annual reports are used to communicate governance issues of an entity, internal matters including the use of modern management accounting techniques are expected to flow into such documents [Ajibolade \& Oyewo, 2017a]. The aspects of the annual report containing information on SMA practice were: Company profile, Chairman Statement, Managing Director's or Chief Executive Officer's Report, Report of the Directors, Chief Finance Officer's review, and Standalone reports on activities of Strategic Business Units (SBUs). To ensure an extensive review and wide coverage of management accounting practice, the annual reports for the 10-year period was examined for each firm. The company's website was also visited to assess disclosure in respect of the research subject matter. Prior studies have used a similar approach of content-analysing annual reports to assess management accounting practice of companies [see Ajibolade \& Oyewo, 2017a, 2017b].

\section{(ii) Sustainable Competitive Advantage}

Sustainable competitive Advantage, in the context of this study, refers to the ability of an organisation to consistently improve and maintain an above-average performance in the medium- to long-term at both the industry level (the category from the seven groups earlier enumerated where a firm operates) and sector level (collection of all the firms across the seven groups/ collection of industries). Competitive advantage was measured at both the industry level and the Sector level. The average Turnover for each of the seven industries and the manufacturing sector as a whole were computed. The Turnover of individual firms was then compared with both the industry average and sector average Turnover over the 10year period (2008-2017). If a firm's Turnover consistently exceed either the industry or Sector average Turnover, it means the company was able to sustain its competitive advantage and is scored ' 1 '. Conversely, if a firm's Turnover falls below either the industry or subsector average, it implies absence of sustainable competitive advantage and is scored ' 0 '.

\subsection{Method of Data Analysis}

Statistical techniques applied to analyse data were descriptive statistics, cluster analysis, cross tabulation, Chi-Square Tests of association, and discriminant analysis. 


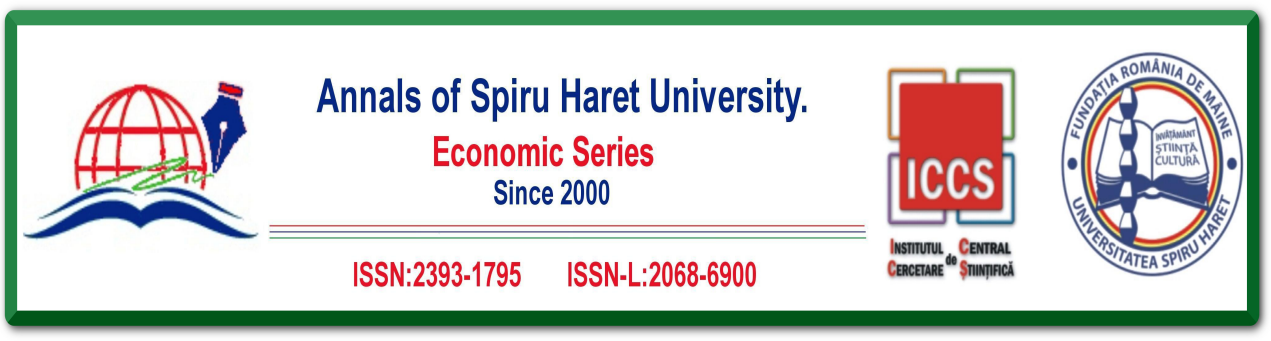

Issue 2/2019

\section{Results and Discussion}

4.1. Adoption Rate of SMA

Table 2a presents descriptive statistics on the adoption level of SMA. $33(58.9 \%)$ firms have scores of 0 to 4 , while $23(41.1 \%)$ of the firms scored from 5 to 7.

Table 2a. Adoption Rate of SMA

\begin{tabular}{|c|c|c|c|c|c|}
\hline & core & Frequency & Percent & Valid Percent & Cumulative Percent \\
\hline \multirow{9}{*}{ Valid } & 0 & 7 & 12.5 & 12.5 & 12.5 \\
\hline & 1 & 4 & 7.1 & 7.1 & 19.6 \\
\hline & 2 & 7 & 12.5 & 12.5 & 32.1 \\
\hline & 3 & 5 & 8.9 & 8.9 & 41.1 \\
\hline & 4 & 10 & 17.9 & 17.9 & 58.9 \\
\hline & 5 & 12 & 21.4 & 21.4 & 80.4 \\
\hline & 6 & 10 & 17.9 & 17.9 & 98.2 \\
\hline & 7 & 1 & 1.8 & 1.8 & 100.0 \\
\hline & Total & 56 & 100.0 & 100.0 & \\
\hline
\end{tabular}

Table 2b. Descriptive Statistics on SMA Adoption Rate

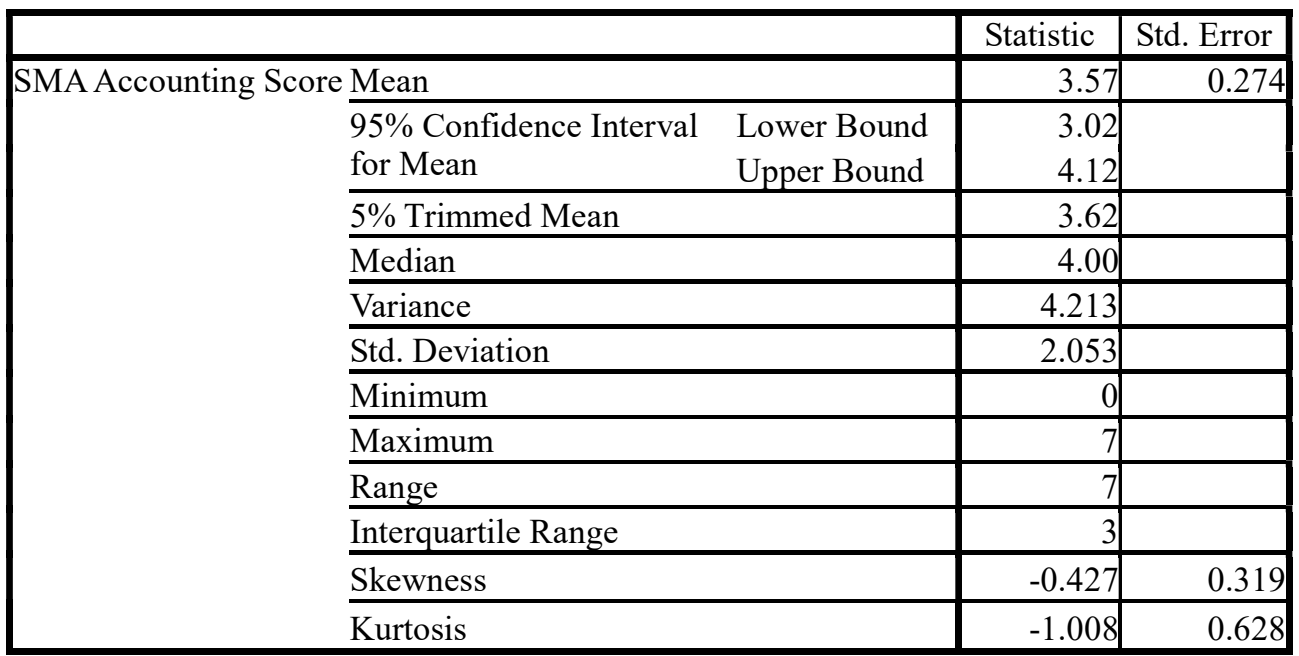




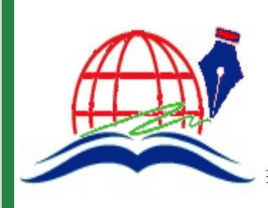

Annals of Spiru Haret University.

Economic Series

Since 2000
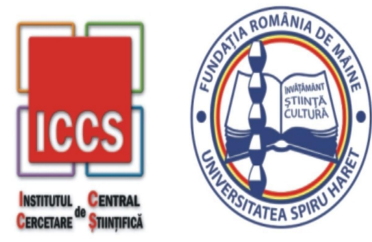

Issue 2/2019

In Table $2 b$, the Minimum value of SMA adoption level is 0 , the maximum is 7 , the Median is 4.0 and the Mean (M) is 3.57. These points are represented in the Box plot and stem-and-leaf plot presented in Appendices 1 and 2. The negative skewness coefficient of -0.427 indicates that there are more data points concentrated to the left of the Mean (low adoption score). In essence, there are more low adopters of SMA than high adopters.

Table 2c. Extreme Values on SMA Adoption Rate

\begin{tabular}{|c|c|c|c|c|}
\hline & & & Case Number & Value \\
\hline \multirow{10}{*}{ SMA Adoption rate } & \multirow[t]{5}{*}{ Highest } & 1 & 33 & 7 \\
\hline & & 2 & 6 & 6 \\
\hline & & 3 & 10 & 6 \\
\hline & & 4 & 16 & 6 \\
\hline & & 5 & 17 & $6^{\mathrm{a}}$ \\
\hline & \multirow[t]{5}{*}{ Lowest } & 1 & 56 & 0 \\
\hline & & 2 & 53 & 0 \\
\hline & & 3 & 31 & 0 \\
\hline & & 4 & 30 & 0 \\
\hline & & 5 & 21 & $0^{b}$ \\
\hline
\end{tabular}

a. Only a partial list of cases with the value 6 is shown in the table of upper extremes.

b. Only a partial list of cases with the value 0 is shown in the table of lower extremes.

Table 2c presents the extreme values for SMA adoption. The first five highest scores are 7, 6, 6, 6 and 6 respectively. Also, the first five lowest scores are all 0s. In Table $2 \mathrm{~d}$, the $50^{\text {th }}$ percentile is 4.0 , while the $75^{\text {th }}$ percentile is the score of 5.0. This implies that at least half of the firms scored 4.0 and below.

The various M-Estimators, used to explore the characteristics of the population such as sample average, range from 3.60 to 3.69 (Table 2e). This is consistent with the Mean of 3.57 (Table 2b), which is an equivalent of $51 \%$ on the 7-point measurement scale. Based on the results in Tables $2 a$ and $2 b$, it is concluded that the adoption rate of customer-based and competitor-focused SMA techniques by manufacturing companies in Nigeria is moderate (research objective one). 


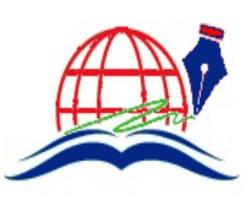

Annals of Spiru Haret University.

Economic Series

Since 2000
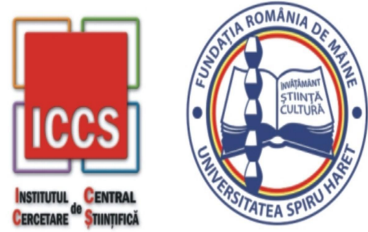

Issue 2/2019

Table 2d. Percentiles Distribution for SMA Adoption Rate

\begin{tabular}{|l|c|c|c|c|c|c|c|}
\hline & \multicolumn{7}{|c|}{ Percentiles } \\
\cline { 2 - 8 } & 5 & 10 & 25 & 50 & 75 & 90 & 95 \\
\hline $\begin{array}{l}\text { Weighted Average SMA Score } \\
\text { (Definition 1) }\end{array}$ & 0.00 & 0.00 & 2.00 & 4.00 & 5.00 & 6.00 & 6.00 \\
\hline Tukey's Hinges SMA Score & & & 2.00 & 4.00 & 5.00 & & \\
\hline
\end{tabular}

Table 2e. M-Estimators for SMA Adoption Rate

\begin{tabular}{|c|c|c|c|c|}
\hline & $\begin{array}{l}\text { Huber's M- } \\
\text { Estimator }^{\mathrm{a}}\end{array}$ & $\begin{array}{c}\text { Tukey's } \\
\text { Biweight }\end{array}$ & $\begin{array}{l}\text { Hampel's M- } \\
\text { Estimator }^{\mathrm{c}}\end{array}$ & $\begin{array}{l}\text { Andrews' } \\
\text { Wave }^{\mathrm{d}}\end{array}$ \\
\hline SMA Adoption Score & 3.69 & 3.67 & 3.60 & 3.67 \\
\hline
\end{tabular}

a. The weighting constant is 1.339 .

b. The weighting constant is 4.685 .

c. The weighting constants are $1.700,3.400$, and 8.500

d. The weighting constant is $1.340 *$ pi.

\subsection{SMA Usage and Sustainable Competitive Advantage}

Firms were categorised into two groups based on their SMA adoption score. Firms with scores from 5-7 (i.e. those with adoption score of $71.4 \%$ and over) were regarded intense users of $S M A$, while others with score ranging from 0-4 were designated non-intense users of SMA. The use of the 5.0 criterion (equivalent of $71.5 \%$ on the 7-point scale) for dichotomising adopters was informed by the consideration that a $70 \%$ adoption rate represent a substantial degree of usage.

The distribution of SMA usage intensity in Table 3 shows that $23(41.1 \%)$ firms are intense users while $33(58.9 \%)$ are non-intense users.

To examine the nexus between SMA usage and competitive position more closely, firms were grouped based on their competitiveness. Hierarchical cluster analysis (using the Wald cluster method and squared Euclidean distance interval), was applied to group firms into three groups of: (i) those earning above-average 


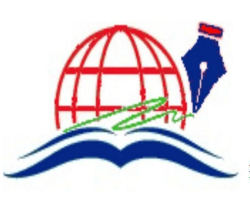

Annals of Spiru Haret University.

Economic Series

Since 2000

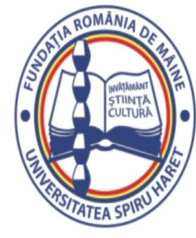

Issue 2/2019

Turnover at both industry and sector level (cluster 3, labelled 'High-flyers'); (ii) those realising above-average Turnover at either industry or sector level (cluster 2, labelled 'Moderate Performers'); (iii) those with below-average Turnover at both industry and sector levels (cluster 1, labelled 'Laggards'). Results of the analysis of intensity of SMA usage and competitive position are presented in Table 4.

Table 3. Intensity of Use of SMA

\begin{tabular}{|c|r|r|r|r|}
\hline SMA usage Intensity & Frequency & Percent & Valid Percent & \multicolumn{2}{|c|}{ Pumulative } \\
\hline Not intense & 33 & 58.9 & 58.9 & 58.9 \\
Intense & 23 & 41.1 & 41.1 & 100.0 \\
Total & 56 & 100.0 & 100.0 & \\
\hline
\end{tabular}

Table 4. Intensity of SMA Usage and Competitive Position of Firms

\begin{tabular}{|c|c|c|c|c|c|}
\hline FIRM CODE & Intensity of SMA Usage & $\begin{array}{c}\text { Did } \\
\text { Company } \\
\text { Turnover } \\
\text { exceed } \\
\text { INDUSTRY } \\
\text { AVERAGE } \\
\text { over the } \\
\text { period? } \\
\end{array}$ & $\begin{array}{c}\text { Did } \\
\text { Company } \\
\text { Turnover } \\
\text { exceed } \\
\text { SECTOR } \\
\text { AVERAGE } \\
\text { over the } \\
\text { period? } \\
\end{array}$ & $\begin{array}{c}\text { CLUSTER } \\
\text { GROUPING } \\
\text { [3 cluster] } \\
\end{array}$ & Competitive Position \\
\hline 1 & Not intense & 0 & 0 & 1 & Laggard \\
\hline 2 & Not intense & 0 & 0 & 1 & Laggard \\
\hline 3 & Not intense & 1 & 0 & 2 & Moderate Performer \\
\hline 4 & Not intense & 1 & 0 & 2 & Moderate Performer \\
\hline 5 & Not intense & 0 & 1 & 3 & High-flyer \\
\hline 6 & Intense & 0 & 0 & 1 & Laggard \\
\hline 7 & Not intense & 0 & 0 & 1 & Laggard \\
\hline 8 & Not intense & 1 & 1 & 3 & High-flyer \\
\hline 9 & Intense & 1 & 1 & 3 & High-flyer \\
\hline 10 & Intense & 1 & 1 & 3 & High-flyer \\
\hline
\end{tabular}




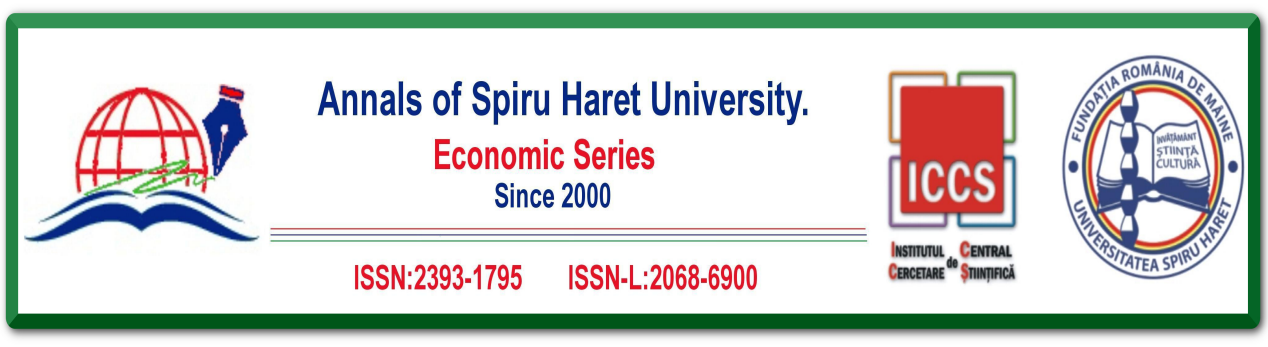

Issue 2/2019

\begin{tabular}{|c|c|c|c|c|c|}
\hline 11 & Intense & 1 & 1 & 3 & High-flyer \\
\hline 12 & Intense & 0 & 1 & 3 & High-flyer \\
\hline 13 & Not intense & 0 & 0 & 1 & Laggard \\
\hline 14 & Not intense & 0 & 0 & 1 & Laggard \\
\hline 15 & Intense & 0 & 0 & 1 & Laggard \\
\hline 16 & Intense & 1 & 1 & 3 & High-flyer \\
\hline 17 & Intense & 1 & 1 & 3 & High-flyer \\
\hline 18 & Not intense & 0 & 0 & 1 & Laggard \\
\hline 19 & Intense & 0 & 1 & 3 & High-flyer \\
\hline 20 & Intense & 0 & 1 & 3 & High-flyer \\
\hline 21 & Not intense & 0 & 0 & 1 & Laggard \\
\hline 22 & Not intense & 0 & 0 & 1 & Laggard \\
\hline 23 & Not intense & 1 & 0 & 2 & Moderate Performer \\
\hline 24 & Intense & 1 & 0 & 2 & Moderate Performer \\
\hline 25 & Intense & 1 & 0 & 2 & Moderate Performer \\
\hline 26 & Not intense & 0 & 0 & 1 & Laggard \\
\hline 27 & Intense & 0 & 0 & 1 & Laggard \\
\hline 28 & Not intense & 0 & 0 & 1 & Laggard \\
\hline 29 & Intense & 0 & 0 & 1 & Laggard \\
\hline 30 & Not intense & 0 & 0 & 1 & Laggard \\
\hline 31 & Not intense & 0 & 0 & 1 & Laggard \\
\hline 32 & Not intense & 0 & 0 & 1 & Laggard \\
\hline 33 & Intense & 0 & 0 & 1 & Laggard \\
\hline 34 & Not intense & 0 & 0 & 1 & Laggard \\
\hline 35 & Intense & 0 & 0 & 1 & Laggard \\
\hline 36 & Not intense & 0 & 0 & 1 & Laggard \\
\hline 37 & Not intense & 0 & 0 & 1 & Laggard \\
\hline
\end{tabular}




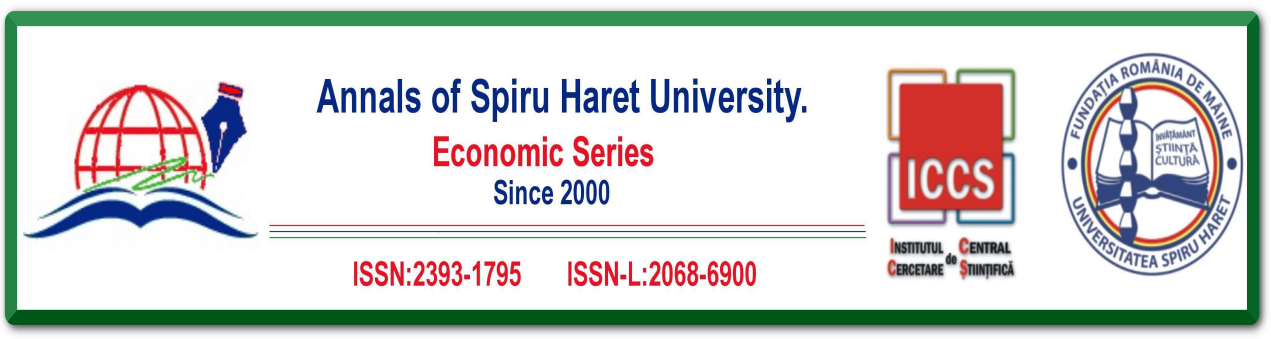

Issue 2/2019

\begin{tabular}{|c|c|c|c|c|c|}
\hline 38 & Not intense & 0 & 0 & 1 & Laggard \\
\hline 39 & Not intense & 0 & 0 & 1 & Laggard \\
\hline 40 & Intense & 1 & 1 & 3 & High-flyer \\
\hline 41 & Not intense & 0 & 0 & 1 & Laggard \\
\hline 42 & Not intense & 0 & 0 & 1 & Laggard \\
\hline 43 & Intense & 0 & 0 & 1 & Laggard \\
\hline 44 & Not intense & 0 & 0 & 1 & Laggard \\
\hline 45 & Intense & 1 & 1 & 3 & High-flyer \\
\hline 46 & Not intense & 0 & 0 & 1 & Laggard \\
\hline 47 & Intense & 0 & 0 & 1 & Laggard \\
\hline 48 & Not intense & 0 & 0 & 1 & Laggard \\
\hline 49 & Intense & 1 & 1 & 3 & High-flyer \\
\hline 50 & Intense & 1 & 1 & 3 & High-flyer \\
\hline 51 & Not intense & 1 & 0 & 2 & Moderate Performer \\
\hline 52 & Intense & 1 & 0 & 2 & Moderate Performer \\
\hline 53 & Not intense & 0 & 0 & 1 & Laggard \\
\hline 54 & Not intense & 0 & 0 & 1 & Laggard \\
\hline 55 & Not intense & 1 & 0 & 2 & Moderate Performer \\
\hline 56 & Not intense & 0 & 0 & 1 & Laggard \\
\hline
\end{tabular}

Source: Authors' Analysis for the Study (2019)

The trend observable in Table 4 is that intense users of SMA belong to the highflyer group in most cases. In effect, high-adopters of SMA were able to consistently achieve above-average performance in the industry where they operate and the manufacturing sector at large (research objective three).

(a) Result from Cross-Tabulation Analysis and Chi-square test of Association Cross-Tabulation and Chi-square test of association was applied to examine whether there is any relationship between SMA usage and competitive position (Tables 5a and 5b). 


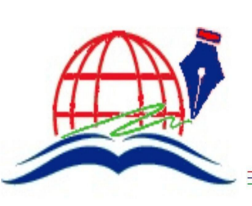

Annals of Spiru Haret University.

Economic Series

Since 2000
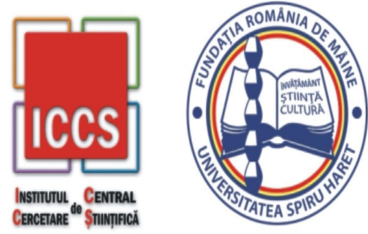

Issue 2/2019

Table 5a. Cross-Tabulation of SMA Usage and Competitive Position of Study Firms

\begin{tabular}{|ll|r|r|r|}
\hline & & \multicolumn{2}{|c|}{ Intensity of use of SMA } & \multirow{2}{*}{ Total } \\
\cline { 3 - 4 } & & not intense & Intense & \multicolumn{2}{c|}{ Tor } \\
Competitive Position & Laggards & 8 & 34 \\
& Moderate performers & 5 & 3 & 8 \\
& High-Flyers & 2 & 12 & 14 \\
Total & & 33 & 23 & 56 \\
\hline
\end{tabular}

In Table 5a, 12 out of the 14 high-flyers are intense users of SMA. This contrasts sharply with 26 out of the 34 laggards that are not intense users. It therefore appears that the intense use of SMA leads to the sustenance of competitive position (research objective three).

Table 5b. Chi-Square Tests of Association Between SMA Usage and Competitive Position

\begin{tabular}{|c|c|c|c|}
\hline & Value & $\mathrm{df}$ & Asymp. Sig. (2-sided) \\
\hline Pearson Chi-Square & $15.893^{\mathrm{a}}$ & 2 & 0.000 \\
\hline Likelihood Ratio & 16.668 & 2 & 0.000 \\
\hline Linear-by-Linear Association & 14.818 & 1 & 0.000 \\
\hline $\mathrm{N}$ of Valid Cases & 56 & & \\
\hline
\end{tabular}
3.29 .

a. 2 cells $(33.3 \%)$ have expected count less than 5 . The minimum expected count is

Chi-square $p$ value of 0.000 is significant at $1 \%$ (Table $5 b$ ), thereby confirming that there is a positive and significant association between SMA usage and Competitive position (research objective two).

(b) Result from Discriminant Analysis

To examine the adoption rate of SMA across competitive positions, the Mean of SMA adoption rate for the three classes of competitiveness was computed (Table 6). 


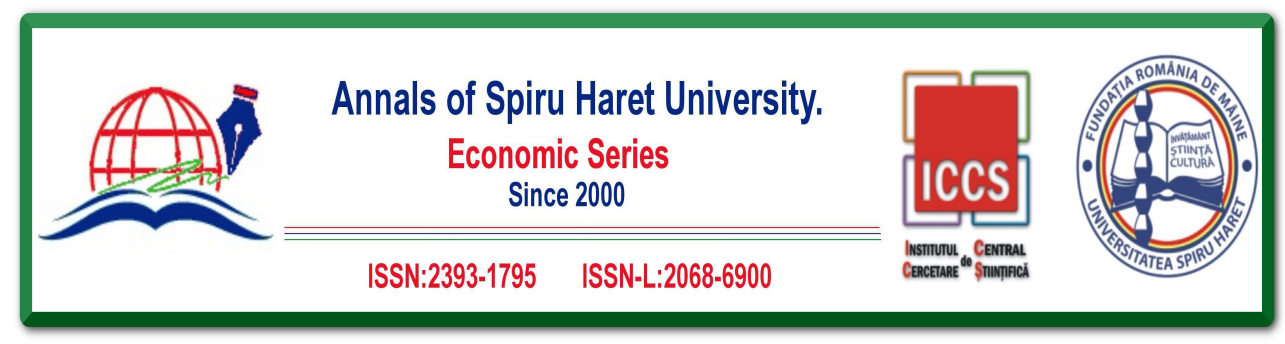

Issue 2/2019

Table 6. Adoption Rate of SMA across Competitive Positions

\begin{tabular}{|l|r|r|r|}
\hline Competitive Position & Adoption rate of SMA & N & Std. Deviation \\
\hline Laggards & 2.82 & 34 & 2.022 \\
Moderate Performers & 4.25 & 8 & 1.165 \\
High-Flyers & 5.00 & 14 & 1.664 \\
Total & 3.57 & 56 & 2.053 \\
\hline
\end{tabular}

Table 7a. Wilks' Lambda

\begin{tabular}{|l|r|r|r|r|}
\hline Test of Function(s) & Wilks' Lambda & Chi-square & df & Sig. \\
\hline 1 & 0.716 & 17.692 & & 2 \\
\hline
\end{tabular}

Table 7b. Classification Results ${ }^{\mathrm{a}}$

\begin{tabular}{|r|l|l|r|r|r|r|}
\hline & & & \multicolumn{3}{|c|}{ Predicted Group Membership } & \multirow{2}{*}{} \\
\cline { 3 - 6 } & & Competitiveness Position & Laggards & $\begin{array}{c}\text { Moderate } \\
\text { Performers }\end{array}$ & $\begin{array}{c}\text { High- } \\
\text { Flyers }\end{array}$ & \multirow{2}{*}{ Total } \\
\hline Original & Count & Laggards & 26 & 0 & 8 & 34 \\
& Moderate Performer & 5 & 0 & 3 & 8 \\
& High-Flyers & 2 & 0 & 12 & 14 \\
\cline { 2 - 6 } & Laggards & 76.5 & 0.0 & 23.5 & 100.0 \\
& Moderate Performers & 62.5 & 0.0 & 37.5 & 100.0 \\
& High-Flyers & 14.3 & 0.0 & 85.7 & 100.0 \\
\hline
\end{tabular}

a. $67.9 \%$ of original grouped cases correctly classified.

The Mean adoption rate of SMA are in the ascending order of 2.82 (Laggards), 4.25 (Moderate Performers), and 5.00 (High-flyers). The adoption rate of SMA seems to vary proportionately with the degree of firms' competitiveness, with High-flyers recording the highest adoption rate and Laggards witnessing the lowest adoption rate. This buttresses the inference that the usage of SMA positively impact competitive advantage (research objective two).

To examine the extent to which the intensity of SMA usage determines the classification of Firms into their competitive positions, discriminant analysis was employed (results presented in Tables 7a to 7c). 


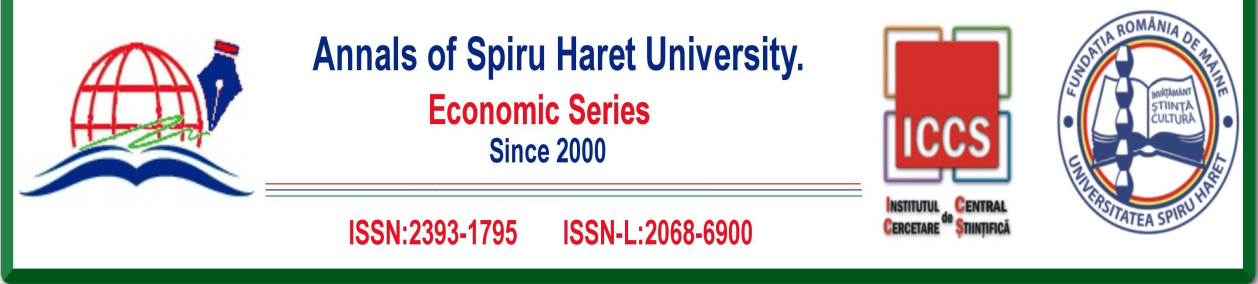

Issue 2/2019

Table 7c. Functions at Group Centroids

\begin{tabular}{|l|r|}
\hline & Function \\
\cline { 2 - 2 } & 1 \\
\hline Level of Competitiveness & -0.410 \\
Moderate Performers & -0.083 \\
High-Flyers & 1.043 \\
\hline
\end{tabular}

The function generated by the discriminant analysis is statistically significant $(\mathrm{p}=$ $0.001<0.01$ ) [Table 7a], implying that the intensity of SMA usage significantly determines the competitive position of firms. The hit ratio of the discriminant analysis at $67.9 \%$ (addition of figures along the principal diagonal; $26+0+12=$ 38/56) (Table 7b) suggests that the discriminant function was fairly accurate in categorising firms into their competitive position based on the usage intensity of SMA. The function at group centroids generated the coefficients of $-0.410,-0.083$ and 1.043 for the competitive positions of Laggards, Moderate Performers, and High-Flyers respectively (Table 7c). The emergence of the High-flyers as the group with the highest coefficient of 1.043 amongst the class of competitiveness connotes that the intense usage of SMA has the strongest connection with this group (the Highflyers). In effect, the extensive use of SMA should lead to high-ranking competitive position.

Overall, the results in Tables 4 to 6 establish that to a large extent, the usage of SMA positively and significantly impact competitive advantage (research objective two), and the intense use of SMA can sustain the competitiveness of firms (research objective three).

\subsection{Test of Hypothesis}

Chi-square test of association established that there is a significant association between SMA usage and competitive position $(\mathrm{p}=0.000<0.01)$ [Table 5b]. SMA adoption rate vary proportionately with the degree of competitiveness, with Highflyers recording the highest adoption rate and Laggards witnessing the lowest adoption rate (Table 6). Discriminant analysis result proves that intensity of SMA usage was able to categorise firms into the three levels of competiveness $(p=0.000$ $<0.01$ ) [Table 7a], with a hit ratio of $67.9 \%$ establishing that the discriminant function was fairly accurate (Table $7 \mathrm{~b}$ ). Intense usage of SMA has the strongest 82 


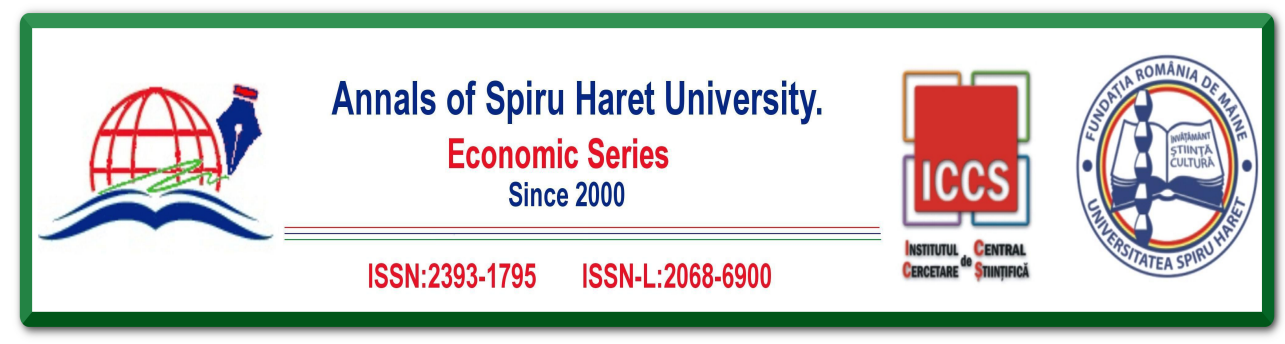

Issue 2/2019

connection with High-flyers (Table 7c). H1 is therefore retained and it is concluded that the usage of SMA has a significant positive impact on sustainable competitive advantage of companies.

\section{Discussion of Findings}

Result suggests that although the frequency of high-adopters of innovative management accounting techniques such as customer accounting and competitor accounting was less than those of low-adopters (Tables $2 \mathrm{a}, 2 \mathrm{~b}$ and $2 \mathrm{~d}$ ), the adoption rate of customer-based and competitor-oriented SMA techniques was noted to be generally moderate (Tables $2 \mathrm{~b}$ and $2 \mathrm{e}$ ) (research objective one). This observation is similar to the results of prior studies on SMA usage in other countries (for example, Askarany, 2009; Jack, 2009; Abdel Al \& McLellan, 2011; Fowzia, 2011; Karanja et al., 2013), as well as in Nigeria (see Chiekezie et al., 2014; Ojua, 2016).

The usage of SMA positively and significantly impacts competitive advantage (research objective two). Further, the use of SMA appears to sustain competitive advantage (research objective three), hence the acceptance of H1. From the 56 companies investigated, 23 firms representing $41.1 \%$ intensely apply SMA (Table 3). 15 out of the 23 intense users of SMA (representing 65.2\%) were able to consistently outperform competitors over the 10-year period at either the industry- or sector-level (Table 5a), while 12 from the 23 intense users (a proportion of 52.2\%) were able to sustain competitive advantage at both - the industry and sector levels. The usage of SMA is significantly associated with the competitiveness of firms (Table 5b). Whereas firms outperforming competitors at both industry and sector levels (the high-flyers) have the highest adoption rate of SMA $(\mathrm{M}=5.00)$, other firms performing above-the-average at either the industry or sector level (the moderate performers) have higher adoption rate $(\mathrm{M}=4.25)$ than firms performing below average at both the industry and sector levels (the Laggards) $[\mathrm{M}=2.82]$ (Table 6). Thus, the intensity of SMA usage is directly related to the competitiveness of firms. Result in Table 7c establish that the extensive use of SMA should lead to highranking competitive position.

The observation that the usage of SMA enhances the competitiveness of firms is consistent with some studies from other countries [Adler et al., 2000; Cadez \& Guilding, 2008; Abdel Al \& McLellan, 2011; Fowzia, 2011; Abdel Al \& McLellan, 2013; Alsoboa et al., 2015; Anna, 2015; Ahmad \& Zabri, 2016; Eker \& Aytaç, 2016], and studies conducted in Nigeria [see Akenbor \& Okoye, 2012; Abogun \& Abomide, 


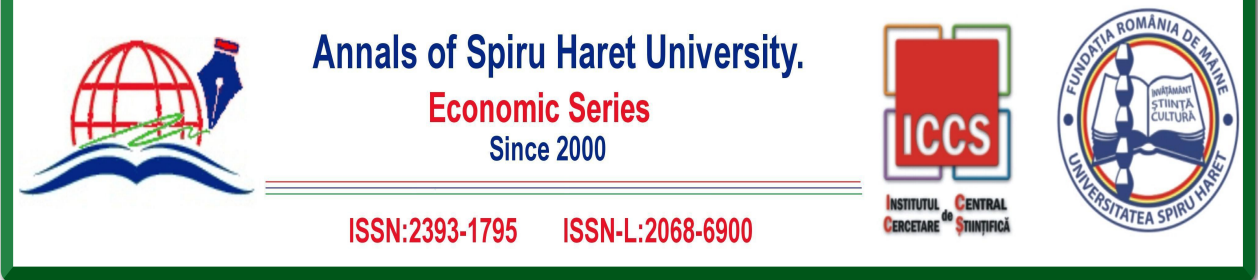

Issue 2/2019

2013; Chiekezie et al., 2014; Oboh \& Ajibolade, 2017]. This study found no evidence to support the contentions of scholars doubting the essence of management accounting techniques [for example, Lord, 1996; Tomkins \& Carr, 1996; Mevellec \& Lebas, 2010].

\section{Conclusion}

This study examined the extent to which the usage of SMA techniques such as customer accounting and competitor accounting could create and sustain competitive advantage. Analysis of data obtained from the annual reports of fifty-six (56) publicly-quoted manufacturing companies in Nigeria revealed that the adoption rate of SMA is moderate (research objective one). The usage of SMA positively and significantly impacts competitive advantage (research objective two). The observation that intense users of SMA were able to consistently outperform competitors over the 10-year period under investigation at both the industry- and sector-level supports the conclusion that, to a large extent, SMA usage sustains competitive advantage (research objective three).

Seeing that the overall adoption rate of SMA by the study companies was moderate at best, the inability of manufacturing companies in Nigeria to favourably compete at the international market may not be unconnected to the unappreciable level of SMA implementation, among other challenges. It is not the mere adoption of SMA that sustains competitive advantage per se as established by the result of this study, but its intense usage. To this end, organisations seeking strategies to improve their competitiveness may consider the rigorous application of SMA.

Acknowledging that the extensive application of SMA would impose requirements on the resources and organisational structure of adopters, management of companies is importuned to remove or at least diminish whatever hindrance that may confront its implementation which may include human barrier, lack of technological equipment, cost, or the subsuming of management accounting function within the financial accounting system. Given the future-orientation of SMA, it is important to stress that the benefits of its usage may not materialise in the short-run but in the medium- to long-term - this is crucial in order not to get discouraged when benefits of implementation do not accrue immediately. 


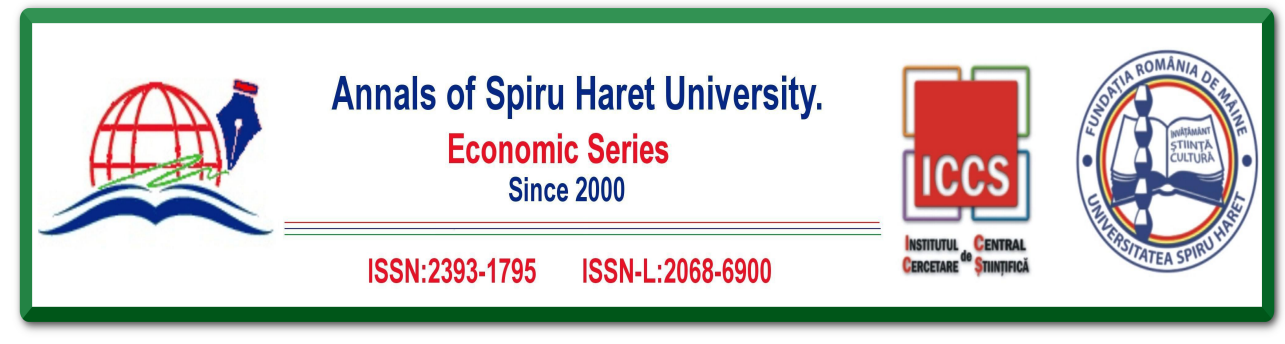

Issue 2/2019

\section{References}

[1] Abdel Al, S.F. \& McLellan J.D. (2011). Management accounting practices in Egypt: A transitional economy Country. Journal of Accounting, Business \& Management, 18(2), 105-120.

[2] Abdel Al, S.F., \& McLellan, J.D. (2013). Strategy and management accounting practices alignment and its effect on organizational performance. Journal of Accounting, Business \& Management, 20 (1), 1-27.

[3] Abdullah, N. H., \& Said, J. (2015). Enhancing the governance of government linked companies via strategic management accounting practices and value creation. Procedia Economics and Finance, 28, 222-229.

[4] Abogun, S., \& Abomide, O. (2013). Adoption level and impact of strategic initiatives in management accounting on firms' performance in Kwara state. Advances in management, 11 (1), 21-31.

[5] Aboramadan, M., \& Borgonovi, E. (2016). Strategic management practices as a key determinant of superior non-governmental organisations performance. Problems of management in the 21st century, 11 (2), 71-92.

[6] Adler, R., Everett, A.M., \& Waldron, M. (2000). Advanced management accounting techniques in manufacturing: Utilization, benefits, and barriers to implementation. Accounting Forum, 24(1), 131-150.

[7] Agasisti, T., Arnaboldi, M., \& Azzone, G. (2008). Strategic management accounting in Universities: The Italian experience. High Education, 55, 1-15. DOI 10.1007/s10734006-9032-6

[8] Ahl, E.B. (1999). An investigation of the influence of culture on management accounting. Master of Commerce thesis, Department of Accounting and Finance, University of Wollongong. Retrieved from http://ro.uow.edu.au/theses/2266

[9] Ahmad, K., \& Zabri, S.M. (2015). Factors explaining the use of management accounting practices in Malaysian medium-sized firms. Journal of Small Business and Enterprise Development, 22(4), 762-781.

[10] Ahmad, K., \& Zabri, S.M. (2016). Management accounting practices among small and medium enterprises. Proceedings of the 28th International Business Information Management Association Conference. 9-10 November 2016, Seville, Spain.

[11] Ajibolade, S.O. (2010). Empirical evidence of the usage and benefits of management accounting techniques in Nigerian companies. Knowledge review, 21(3), 69-79

[12] Ajibolade, S.O., \& Oyewo, B. (2017a). Firm characteristics and performance disclosure in annual reports of Nigerian banks using the balanced scorecard. EuroEconomica, 36 (1), 94-112. Retrieved from http://journals.univ-danubius.ro/ index.php/euroeconomica/article/ view/3872/4004

[13] Ajibolade, S.O., \& Oyewo, B.M. (2017b). Evaluation of multi-perspective performance reporting in Nigerian banks using the balanced scorecard model. International Accounting \& Finance Research Journal, 6 (1), 43-63. 


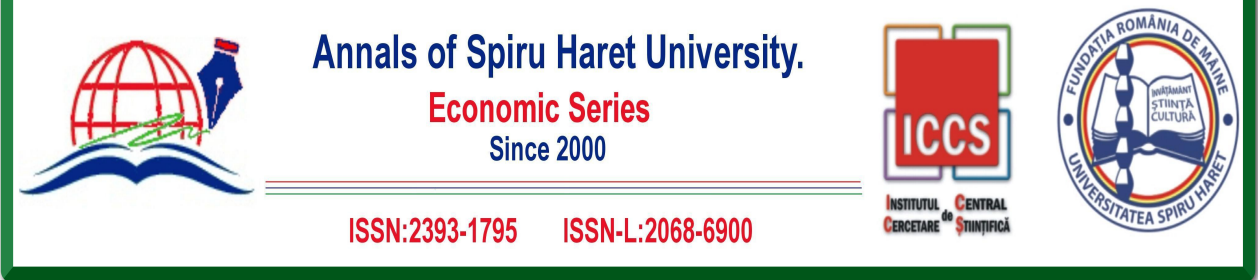

\section{Issue 2/2019}

[14] Akenbor, C.O., \& Okoye E.I. (2012). The adoption of strategic management accounting in Nigerian manufacturing firms. International Journal of Arts and Humanities, 1(3), 270-287.

[15] Al-Mawali, H. (2015). Contingent factors of strategic management accounting. Research Journal of Finance and Accounting, 6 (11), 130-137.

[16] Alsoboa, S., Al-Ghazzawi, A., \& Joudeh, A. (2015). The impact of strategic costing techniques on the performance of Jordanian listed manufacturing companies. Research Journal of Finance and Accounting, 6 (10), 116-127.

[17] Angelakis, G., Theriou, N., \& Floropoulos I. (2010). Adoption and benefits of management accounting practices: Evidence from Greece and Finland. Advances in Accounting, incorporating Advances in International Accounting, 26, 87-96.

[18] Anna, A. (2015). Strategic management tools and techniques and organizational performance: Findings from the Czech Republic. Journal of Competitiveness, 7 (3), 19-36.

[19] Askarany, D. (2009). An investigation into the diffusion of cost and management accounting innovations in Australia. Retrieved from https://dx.doi.org/10.2139/ ssrn. 1445439

[20] Barney, J. B. (2002). Gaining and sustaining competitive advantage ( $2^{\text {nd }}$ ed.). Reading, Mass: Addison-Wesley.

[21] Bhimani, A., \& Bromwich, M. (1992). Management accounting: Evolution in progress. In C. Drury (Ed.), Management accounting handbook. Oxford: Wiley.

[22] BPP (2008). CIMA Paper P2: Management accounting - decision management study text . (5 ${ }^{\text {th }}$ Ed.). London: BPP Learning Media Ltd.

[23] BPP (2009a). CIMA Paper P3: Performance Strategy study text. ( $1^{\text {st }}$ Ed.). London: BPP Learning Media Ltd.

[24] BPP (2009b). CIMA Paper E3: Enterprise Strategy study text. ( $1^{\text {st }}$ Ed.). London: BPP Learning Media Ltd.

[25] Bromwich, M., \& Bhimani, A. (1989). Management accounting: Evolution not revolution. London: The Chartered Institute of Management Accountants Publishing.

[26] Bromwich, M., \& Bhimani, A. (1994). Management accounting pathways to progress. London: Chartered Institute of Management Accountants.

[27] Cadez, S., \& Guilding, C. (2008). An exploratory investigation of an integrated contingency model of strategic management accounting. Accounting, Organisations and Society, 33(7-8), 836-863.

[28] Chartered Global Management Accountants, CGMA (2014). Consultation draft: Global Management Accounting Principles. Retrieved from the Chartered Global Management Accountants website: http://www. cgma.org

[29] Chartered Global Management Accountants, CGMA (2015). Global Management Accounting Principles. Retrieved from the Chartered Global Management Accountants website: http://www. cgma.org 


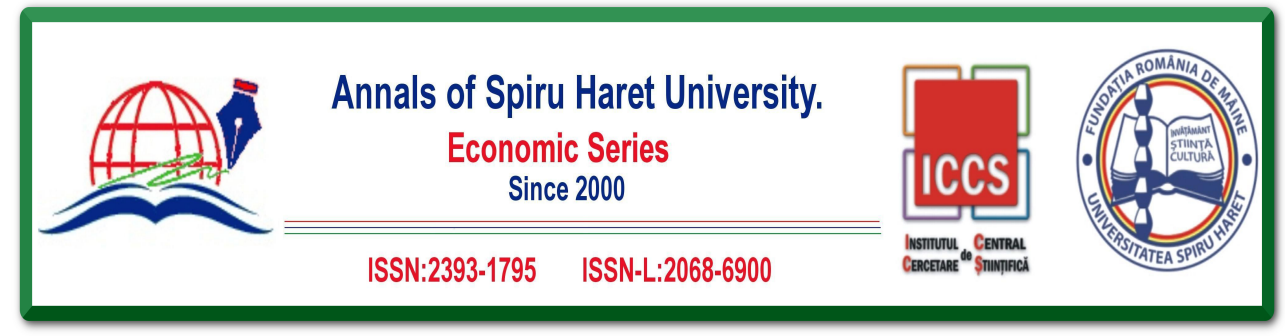

Issue 2/2019

[30] Chartered Institute of Management Accountants, CIMA (2002). Latest trends in performance management. UK: Technical briefing paper.

[31] Chenhall, R., \& Langfield-Smith, K. (1998). Adoption and benefits of management accounting practices: An Australian study. Management accounting research, 9, 1-19.

[32] Chiekezie, N.R., Egbunike, P.A., \& Odum, A.N. (2014). Adoption of competitor focused accounting methods in selected manufacturing companies in Nigeria. Asian Journal of Economic Modelling, 2(3), 128-140.

[33] Cinquini L., \& Tenucci A. (2007). Is the adoption of strategic management accounting techniques really "strategy-driven"? Evidence from a survey, 1-27. Retrieved from http://mpra.ub.uni-muenchen.de/11819/

[34] Cooper, R., \& Kaplan, R.S. (1988). Measure costs right: Make the right decisions. Harvard Business Review, 88 (5), 96-103.

[35] Drury, C. (1992). Introduction. In C. Drury (Ed.), Management accounting handbook. Oxford: Butterworth-Heinemann.

[36] Eker, M., \& Aytaç, A. (2016). Effects of interaction between ERP and advanced managerial accounting techniques on firm performance: Evidence from Turkey. The Journal of Accounting and Finance, Oct, 187-209.

[37] Emerton, P., \& Jones, A. (2019). Perceptions of the efficacy of sustainability-related performance conditions in executive pay schemes. Journal of Sustainable Finance \& Investment, 9 (1), 1-16.

[38] Ferreira, M., Sobreiro, V., Kimura, H., \& Barboza, F. (2016). A systematic review of literature about finance and sustainability. Journal of Sustainable Finance \& Investment, $6(2), 112-147$.

[39] Fowzia, R. (2011). Strategic management accounting techniques: Relationship with business strategy and strategic effectiveness of manufacturing organizations in Bangladesh. World Journal of Management, 3 (2), 54-69.

[40] Guilding, C., Cravens, K.S., \& Tayles, M. (2000). An international comparison of strategic management accounting practices. Management Accounting Research, 11, 113135.

[41] Holm, M., Kumar, V., \& Plenborg, T. (2016). An investigation of customer accounting systems as a source of sustainable competitive advantage. Advances in Accounting, 32, 18-30. DOI: $10.1016 / \mathrm{j}$.adiac.2015.12.002.

[42] Hoque, Z. (2002). Strategic management accounting: Concepts, processes and issues. London: Spiro Press.

[43] Hyvonen, J. (2005). Adoption and benefits of management accounting systems: Evidence from Finland and Australia. Advances in International Accounting, 18, 97-120.

[44] International Federation of Accountants, IFAC. (1998). International management accounting practice statement: Management Accounting Concepts. New York: IFAC. 


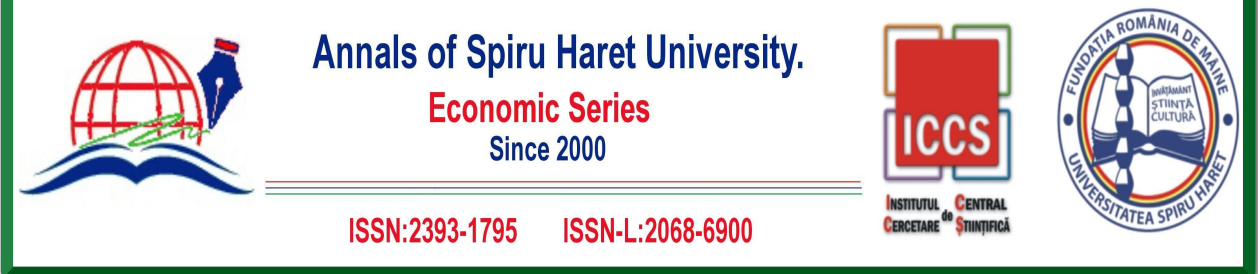

\section{Issue 2/2019}

[45] Jack, L. (2009). The adoption of strategic management accounting tools in agriculture post subsidy reform: A comparative study of practices in the UK, the US, Australia and New Zealand. CIMA Research executive summaries series, 5 (7), 1-7. Retrieved from https://www.cimaglobal.com/Documents/Thought_leadership_docs/2009-12-16cid_ressum_adoption_strategic_management_accounting_tools_sept09.pdf

[46] Kaplan (2013). ACCA Paper F2: Management accounting. Berkshire, UK: Kaplan Publishing Limited.

[47] Kaplan, R. S., \& Atkinson, A. A. (1989). Advanced management accounting (2nd ed.). Upper Saddle River: Prentice Hall.

[48] Karanja, J., Mwangi, E., \& Nyaanga, P. (2013). Adoption of modern management accounting techniques in small and medium (SMEs) in developing Countries: A case study of SMEs in Kenya. Retrieved from https://pdfs.semanticscholar.org/ 6c29/7694a3415428f076a72b603c879baee6503e.pdf

[49] Ku, H., Mustapha, U.M., \& Goh, S. (2010). A literature review of past and present performance of the Nigerian manufacturing sector. Journal of Engineering Manufacture, 224 (12), 1894-1904. DOI: 10.1243/09544054JEM1818

[50] Kushwaha, G. S. (2011). Competitive advantage through information and communication technology enabled supply chain management practices. International Journal of Enterprise Computing and Business Systems, 1 (2), 1-13.

[51] Langfield-Smith, K. (2008). Strategic management accounting: How far have we come in 25 years? Accounting, Auditing \& Accountability Journal, 21(2), 204-228.

[52] Lord, B. R. (1996). Strategic management accounting: The Emperor's new clothes? Management Accounting Research, 7, 347-366.

[53] Njuki, H. M., Okoth, O. M., Mutua, M. W., \& Mwangómbe, C. W. (2013). Analysis of information and communication technology on service innovation and competitive advantage: A case of commercial banks in Kenya. European Journal of Business and Management, 5 (17), 1-8.

[54] Noordin, R., Zainuddin, Y., \& Tayles, M. (2009). Strategic management accounting information elements: Malaysian evidence. Asia-Pacific Management Accounting Journal, 4(1), 17-34.

[55] Oboh, C. S., \& Ajibolade, S. O., (2017). Strategic management accounting and decision making: A survey of the Nigerian Banks. Future Business Journal, 3(2), 119137. doi: http://dx.doi.org/10.1016/j.fbj.2017.05.004.

[56] Ojua, M. (2016). Strategic management accounting practices among indigenous Nigerian manufacturing enterprises. Open science Journal, 1 (2), 1-15.

[57] Ojua, M. O. (2017). The desirability of the adoption of strategic management accounting techniques (SMATS) for decision making by agricultural firms in Nigeria. Imperial Journal of Interdisciplinary Research, 3 (1), 1635-1648. 


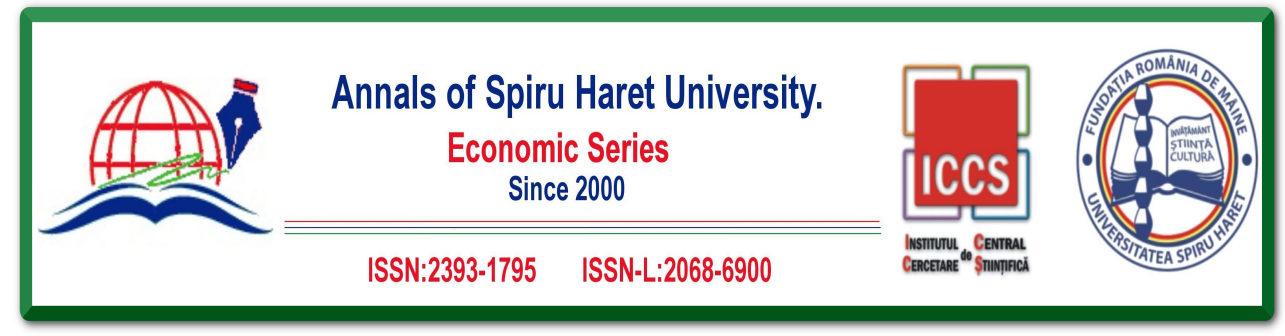

Issue 2/2019

[58] Oyewo, B., Ajibolade, S., \& Obazee, A. (2019).The influence of stakeholders on management accounting practice. Journal of Sustainable Finance \& Investment. DOI: https://doi.org/10.1080/20430795.2019.1619336

[59] Pavlatos, O. \& Paggios, I. (2007). Cost accounting in Greek hotel enterprises: An empirical approach. MPRA Paper 6364, University Library of Munich, Germany.

[60] Pavlatos, O. (2011). Strategic management accounting techniques: The impact of CFO characteristics, organizational lifecycle stage, and quality of IS information. European accounting association, 3rd annual meeting, 19-22 April 2011, Auditorium Parco Della Musica \& Lusis University, Rome, Italy.

[61] Pitcher, G.S. (2015). Management accounting in support of the strategic management process. CIMA Executive Summary Report, 11 (1), 1-20. Retrieved from https://www.cimaglobal.com/Research--Insight/Management-accounting-in-support-ofthe-strategic-management-process/

[62] Porter, M., \& Millar, V. E. (1985). How information gives you competitive advantage. Harvard Business Review, 63(4), 149-160.

[63] Roslender R. \& Hart, S.J. (2002). Integrating management accounting and marketing in the pursuit of competitive advantage: The case for strategic management accounting. Critical Perspectives on Accounting, 13, 255-277.

[64] Roslender, R., \& Hart, S. J. (2003). In search of strategic management accounting: Theoretical and field study perspectives. Management Accounting Research, 14 (1), 255-279.

[65] Shank, J. K. \& Govindarajan, V. (1992). Strategic cost management: The value chain perspective. Journal of Management Accounting Research, 4, 179-197.

[66] Shank, J. K., \& Govindarajan, V. (1989). Strategic cost analysis. Homewood, Illinois: Irwin.

[67] Simmonds, K. (1981). Strategic management accounting. Management Accounting, $59,26-29$.

[68] Subasinge, J., \& Fonseka, A. (2009). Factors affecting the low adoption of management accounting practices in Sri Lankan business organisations. Sri Lankan Journal of Management, 14 (2), 95-114.

[69] Sulaiman, M., Ahmad N., \& Alwi, N. (2004). Management accounting practices in selected Asian Countries: A review of the literature. Managerial Auditing Journal, 9(4), 493-508.

[70] Tomkins, C., \& Carr, C. (1996). Reflections on the papers in this issue and a commentary on the state of strategic management accounting. Management Accounting Research, 7 (2), 271-280.

[71] Yap, K.H.A., Lee, T.H., Said, J., \& Yap, S.T. (2013). Adoption, benefits and challenges of strategic management accounting practices: Evidence from emerging market. Asia Pacific Management Accounting Journal, 8(2), 27-45. 


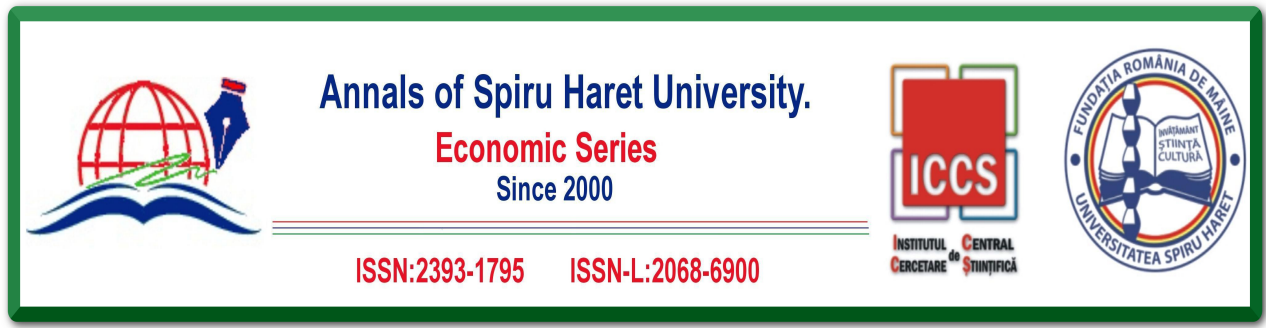

Issue 2/2019

APPENDIX 1: BOX AND WHISKER PLOT FOR SMA ADOPTION RATE

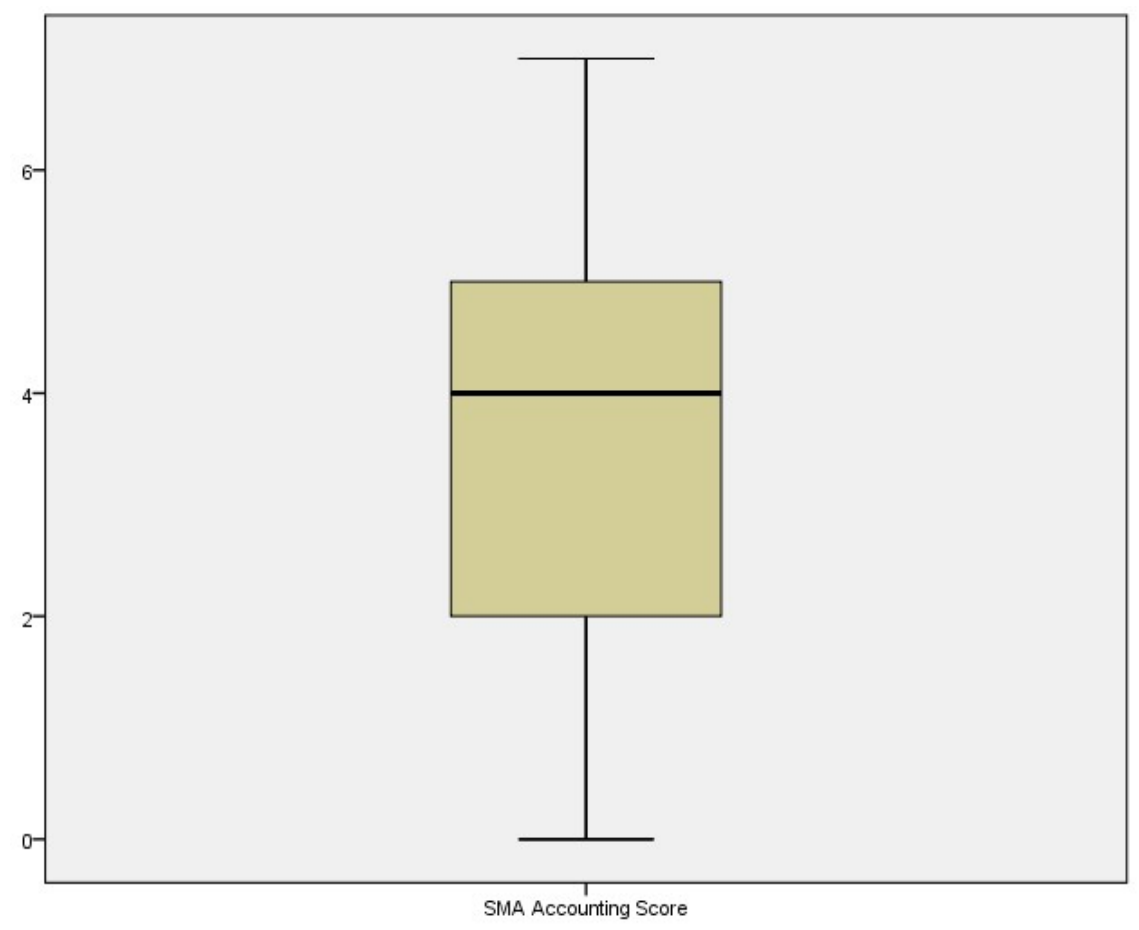




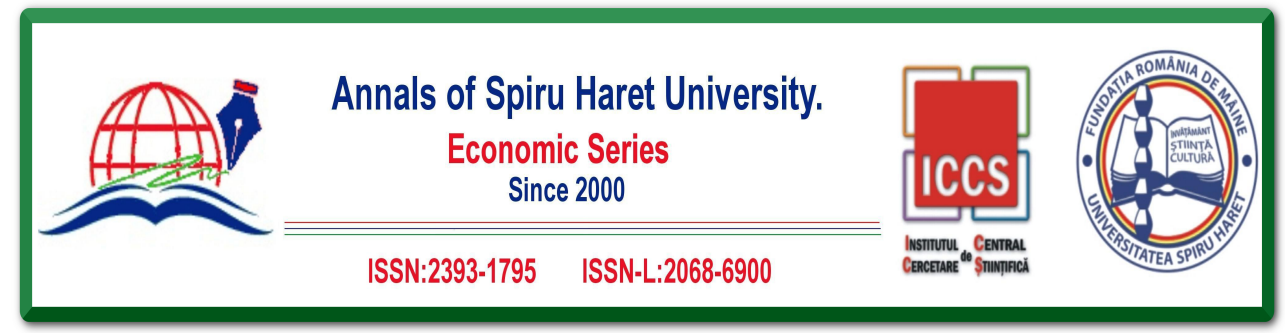

Issue 2/2019

\section{APPENDIX 2: STEM-AND-LEAF PLOT FOR SMA ADOPTION RATE}

Frequency Stem \& Leaf

$\begin{array}{cl}7.00 & 0.0000000 \\ 4.00 & 1.0000 \\ 7.00 & 2.0000000 \\ 5.00 & 3.00000 \\ 10.00 & 4.0000000000 \\ 12.00 & 5.000000000000 \\ 10.00 & 6.0000000000 \\ 1.00 & 7.0\end{array}$

Stem width: $\quad 1$

Each leaf: 1 case(s) 
